\title{
O-GIcNAcylation reduces phase separation and aggregation of the EWS N-terminal low complexity region
}

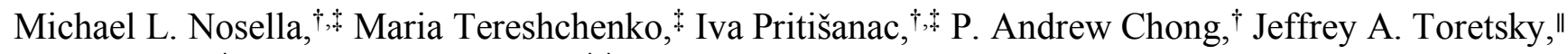 \\ Hyun O. Lee, ${ }^{\ddagger}$ Julie D. Forman-Kay*,†, \\ 'Molecular Medicine Program, The Hospital for Sick Children, Toronto, ON M5G 0A4, Canada; \\ tDepartment of Biochemistry, University of Toronto, Toronto, ON M5S 1A8, Canada; \\ "Departments of Oncology and Pediatrics, Georgetown University, Washington, DC 20057, USA.
}

Keywords: Biomolecular Condensates, Phase Separation, O-GlcNAc, FET proteins, EWS, low complexity regions

\begin{abstract}
Many membraneless organelles are thought to be biomolecular condensates formed by phase separation of proteins and other biopolymers. Post-translational modifications (PTMs) can impact protein phase separation behavior, although for many PTMs this aspect of their function is unknown. $O$-linked $\beta$-D- $N$-acetylglucosaminylation ( $O$-GlcNAcylation) is an abundant form of intracellular glycosylation whose roles in regulating biomolecular condensate assembly and dynamics have not been delineated. Using an in vitro approach, we found that $O$-GlcNAcylation reduces the phase separation propensity of the EWS $N$-terminal low complexity region $\left(\mathrm{LCR}_{\mathrm{N}}\right)$ under different conditions, including in the presence of the arginine- and glycine-rich RNA-binding do-

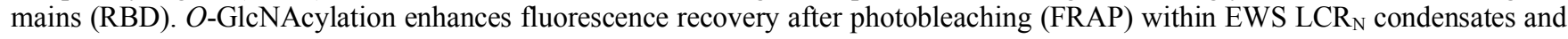
causes the droplets to exhibit more liquid-like relaxation following fusion. Following extended incubation times, EWS LCR + RBD condensates exhibit diminished FRAP, indicating a loss of fluidity, while condensates containing the $O$-GlcNAcylated $\mathrm{LCR}_{\mathrm{N}}$ do not. In HeLa cells, EWS is less $O$-GlcNAcylated following $O G T$ knockdown and more prone to aggregation based on a filter retardation assay. Relative to the human proteome, $O$-GlcNAcylated proteins are enriched with regions that are predicted to phase separate, suggesting a general role of $O$-GlcNAcylation in regulation of biomolecular condensates.
\end{abstract}

\section{INTRODUCTION}

The intracellular spaces of living cells are organized into sub-compartments, many of which lack an encapsulating lipid membrane. Several of these 'membraneless' compartments are now understood to be condensates formed by phase separation of their constituent biomolecules ${ }^{1-3}$. Phaseseparated condensates can provide unique physical and chemical environments which may contribute to the regulation of diverse biological processes. Determining which mechanisms exist to modulate condensate properties is therefore crucial for understanding their functional (or pathological) roles.

Biological polymers such as proteins and nucleic acids undergo phase separation due to cohesive, multivalent intermolecular interactions. The numbers and types of interactions derive from physicochemical sequence properties, which, in the case of proteins, are further enrichened by posttranslational modifications (PTMs) ${ }^{4,5}$. PTMs can impact various aspects of condensates, ranging from composition to larger-scale morphological properties and formation/disassembly kinetics ${ }^{6-8}$. Consistent with a role for PTMs in modulation of phase separation, the numbers of phosphorylation and methylation sites occurring on proteins statistically correlate with their likelihood to phase separate due to interactions involving pi-contacts ${ }^{9,10}$. While PTMs play important and nuanced roles in regulating biological phase separation, for many PTMs this aspect of their function has remained unexplored.

$O$-linked $\quad \beta$-D- $N$-acetylglucosaminylation $\quad$ (' $O$ GlcNAc'ylation) is a form of glycosylation occurring in the nucleus, mitochondria and cytoplasm of higher eukaryotic cells ${ }^{11,12}$. Distinct from the often polymeric and structurally complex extracellular glycans, intracellular $O$ GlcNAcylation entails the reversible modification of serine and threonine $O$-hydroxyl groups with a single GlcNAc moiety. In humans and most other metazoa, addition and removal of $O$-GlcNAc are catalyzed by a single pair of enzymes, $O$-GlcNAc transferase (OGT) and $O$-GlcNAc hydrolase (OGA), respectively, which together regulate modification of over a thousand proteins (currently known) with diverse functions ${ }^{11,13-18}$. Although $O$-GlcNAcylation is enriched in cellular condensates, such as stress granules ${ }^{19}$ and DNA damage puncta ${ }^{20}$, its roles in regulating the formation and physical properties of these and potentially other condensates are poorly understood.

$O$-GlcNAcylation has been found to reduce aggregation and affect phase behavior of certain proteins. For example, $O$-GlcNAcylation of the Drosophila melanogaster Polyhomeotic protein enables its incorporation into functional 
bioRxiv preprint doi: https://doi.org/10.1101/2021.05.11.443654; this version posted May 11, 2021. The copyright holder for this preprint (which was not certified by peer review) is the author/funder, who has granted bioRxiv a license to display the preprint in perpetuity. It is made available under aCC-BY-NC 4.0 International license.

Polycomb repressive complexes by repressing aggregation of its sterile alpha motif domain ${ }^{21}$. O-GlcNAcylation of the nuclear pore complex enhances its passivity and selectivity by tempering interactions between FG-Nups which are otherwise prone to aggregation ${ }^{22}$. Furthermore, $O$ GlcNAcylation of alpha-synuclein ${ }^{23,24}$ and tau ${ }^{25}$ inhibits their self-association into pathological fibrillar states commonly associated with neurodegenerative disorders.

The connection between phase separation and protein aggregation is highlighted by recent reports of liquid-like condensates preceding (or promoting) aggregate states through liquid-to-solid phase transitions ${ }^{26-29}$, particularly in the case of RNA-binding proteins (RBPs) such as FUS ${ }^{30}$ and hnRNPA1 ${ }^{31,32}$. Liquid-to-solid phase transitions often rely on regions of low sequence complexity (LCRs), particularly prion-like domains (PLDs) ${ }^{30,33-36}$, so-called because of their compositional similarities to bona fide yeast prion proteins ${ }^{37}$. Perturbations that affect the strengths and/or numbers of protein-protein interactions can affect whether condensates are biased towards more liquid-like or solid-like material states ${ }^{30,38-43}$. For example, serine/threonine phosphorylation of the FUS $N$-terminal LCR, which is a PLD, reduces its phase separation propensity as well as its ability to form fibrils by disrupting cohesive cross-beta type interactions between LCR monomers ${ }^{40,44}$. Conversely, neurodegenerative disease mutations in FUS and hnRNPA2 can enhance the rate of liquid-to-solid phase transitions by increasing the stabilities of fibrillar structures within initially-liquid condensates ${ }^{30,38}$. Fine-tuning of condensates' physical properties can impact physiological functions as well ${ }^{45-48}$. Defining how PTMs alter particular condensate material properties is therefore of considerable relevance for understanding condensate function and dysfunction.

The Ewing Sarcoma Breakpoint Region 1 (EWS) protein, a member of the FUS-EWS-TAF15 (FET) protein family that has been frequently examined in the phase separation literature ${ }^{33,41,49-53}$, is known to be $O$-GlcNAcylated in vivo ${ }^{54}$. Given that $O$-GlcNAc reduces protein aggregation and that the EWS N-terminal LCR $\left(\mathrm{LCR}_{\mathrm{N}}\right)$ is a PLD with potential for aggregation, we hypothesized that $O$-GlcNAc could modulate the interactions that drive liquid-liquid phase separation of EWS LCRs. Taking an in vitro approach, we found that $O$-GlcNAcylation raises the saturation concentration at which the EWS $\mathrm{LCR}_{\mathrm{N}}$ self-assembles into condensates, including in the presence of the $C$-terminal RNA-binding domains (RBD). $O$-GlcNAcylated EWS $\mathrm{LCR}_{\mathrm{N}}$ droplets exhibit more liquid-like relaxation and diffusive behavior than unmodified droplets, which behave more like static aggregates. Condensates containing both the EWS $\mathrm{LCR}_{\mathrm{N}}$ and RBD lose their rapid internal FRAP over time and $O$-GlcNAcylation prevents this. By silencing OGT expression in HeLa cells, we found that lower $O$-GlcNAcylation levels correlated with increased retention of EWS in a filter retardation assay, suggesting that $O$-GlcNAcylation directly affects EWS solubility in cells as it does in vitro. From a bioinformatic analysis, we found that a significantly greater fraction of $O$ GlcNAcylated proteins are predicted to phase separate compared to the human proteome as a whole. Based on our results, we propose that $O$-GlcNAcylation could regulate the fluidity and function of LCR-containing biomolecular condensates in vivo.

\section{RESULTS}

While all three FET proteins share similar sequence characteristics and cellular localization tendencies, EWS is the sole member shown to be $O$-GlcNAcylated with high stoichiometry in vivo ${ }^{54}$. All three FET proteins contain $N$ - and $C$-terminal LCRs (Figure 1A) which undergo phase separation in different contexts, though we did not know if both of these regions in EWS are $O$-GlcNAcylated ${ }^{55}$. To test the effect of $O$-GlcNAc on EWS phase separation, we purified the $\mathrm{LCR}_{\mathrm{N}}$ (residues 1-264) and $C$-terminal RBD (residues 265-656) and modified them with recombinant, Homo sapiens OGT (nucleocytoplasmic isoform, $110 \mathrm{kDa}{ }^{56}$ ) using the sugar donor substrate, uridine 5'-diphospho- $N$ acetylglucosamine (UDP-GlcNAc) (Figure 1B). We used electrospray ionization mass spectrometry coupled to liquid chromatography (ESI LC-MS) to assess $O$-GlcNAcylation stoichiometry following the reactions (Figure S1). Following an overnight $O$-GlcNAcylation reaction, $\mathrm{LCR}_{\mathrm{N}}$ spectra displayed a set of peaks with incremental mass differences of $\sim 203 \mathrm{Da}$ consistent with discrete $O$-GlcNAc modification states ranging from 3 to 10 moieties per $\mathrm{LCR}_{\mathrm{N}}$ molecule (Figure 1C, S1A, S1B). The same splitting pattern was not achieved with a catalytically-inactive OGT mutant (K842M), demonstrating a lack of modification in the absence of OGT catalysis (Figure S1C). Spectra of the RBD showed negligible changes, indicating that this region is not $O$ GlcNAcylated in vitro (Figure S1D). The distribution of $O$ GlcNAc stoichiometries on the $\mathrm{LCR}_{\mathrm{N}}$ is consistent with previous reports showing a range of $O$-GlcNAcylation states in vivo for EWS ${ }^{54,57}$. We conclude that only the $N$-terminal portion of the EWS preceding the RBD is subject to $O$ GlcNAcylation in vitro.

Like the $N$-terminal LCR of FUS, the EWS $\mathrm{LCR}_{\mathrm{N}}$ selfassociates into hydrogels and induces sedimentation of the chimeric fusion protein EWS-FLI1 in vitro ${ }^{41,53}$, leading us to hypothesize that the EWS $\mathrm{LCR}_{\mathrm{N}}$ could also form liquidlike droplets on its own. Addition of the EWS $\operatorname{LCR}_{N}(30 \mu \mathrm{M})$ into buffer solutions at $\mathrm{pH} 7.5$ with $500 \mathrm{mM} \mathrm{NaCl}$ immediately resulted in the formation of round, micron-sized foci (hereafter termed 'droplets') which were absent at lower salt concentrations (Figure 1D). Droplet formation correlated with increasing $\mathrm{NaCl}$ and $\mathrm{LCR}_{\mathrm{N}}$ concentrations in a similar manner as the FUS $\mathrm{LCR}_{\mathrm{N}}{ }^{58}$ (Figure 1E). To test the influence of $O$-GlcNAc on droplet formation, we purified milligram quantities of the $O$-GlcNAcylated EWS $\mathrm{LCR}_{\mathrm{N}}$ from a scaled-up OGT reaction (see SI Methods). The $O$ GlcNAcylated $\mathrm{LCR}_{\mathrm{N}}$ formed droplets with similar morphologies as the unmodified protein, albeit at higher $\mathrm{NaCl}$ and protein concentrations (Figure 1E,F), implying that $O$ GlcNAc lowers the propensity of the EWS $L_{C R}$ to phase separate under these conditions. Like the FUS LCR, we also expected EWS LCR $\mathrm{N}_{\mathrm{N}}$ phase separation to occur at decreasing temperatures in accordance with upper critical solution temperature-type behavior ${ }^{58}$. We found that unmodified $\mathrm{LCR}_{\mathrm{N}}$ samples at $\mathrm{pH} 7.5$ in the presence of $100 \mathrm{mM} \mathrm{NaCl}$ (i.e., below saturating conditions at room temperature) became turbid as the temperature was decreased below $\sim 16^{\circ} \mathrm{C}$, indicating droplet formation below this temperature (Figure $1 \mathrm{G}$ circle). Increasing the fraction of $O$-GlcNAcylated $\mathrm{LCR}_{\mathrm{N}}$ in the samples led to an incremental lowering of the saturation temperature (Figure $1 \mathrm{G}$ triangle, 
bioRxiv preprint doi: https://doi.org/10.1101/2021.05.11.443654; this version posted May 11, 2021. The copyright holder for this preprint (which was not certified by peer review) is the author/funder, who has granted bioRxiv a license to display the preprint in perpetuity. It is made available under aCC-BY-NC 4.0 International license.

A

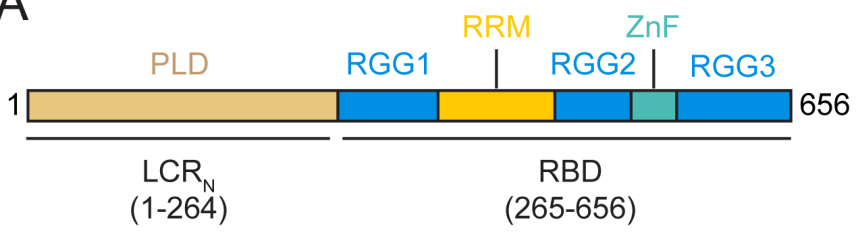

B

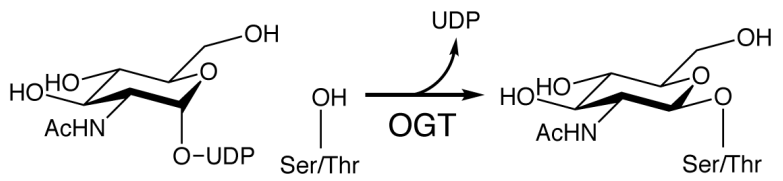

D

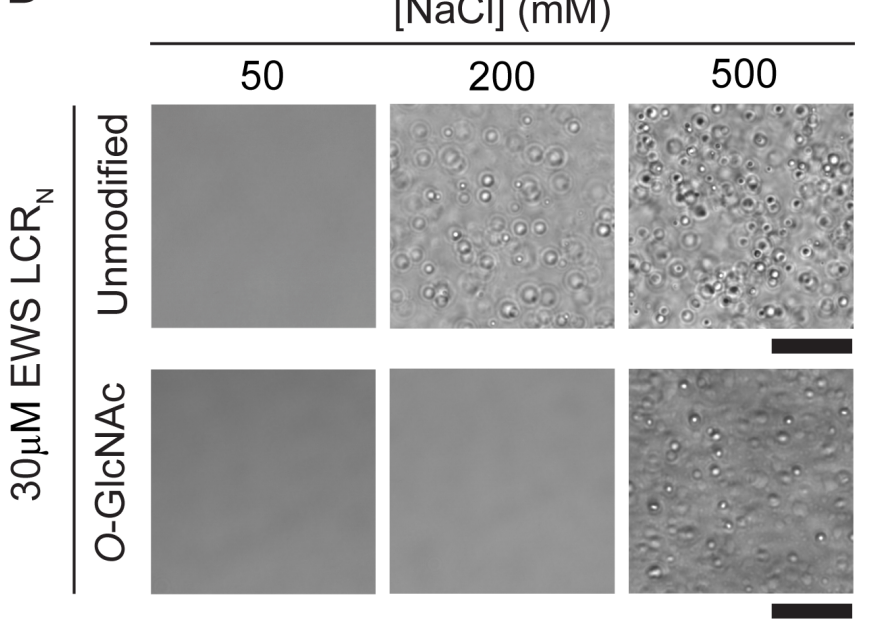

E

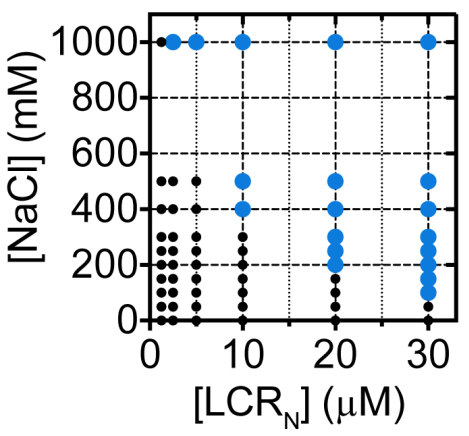

C
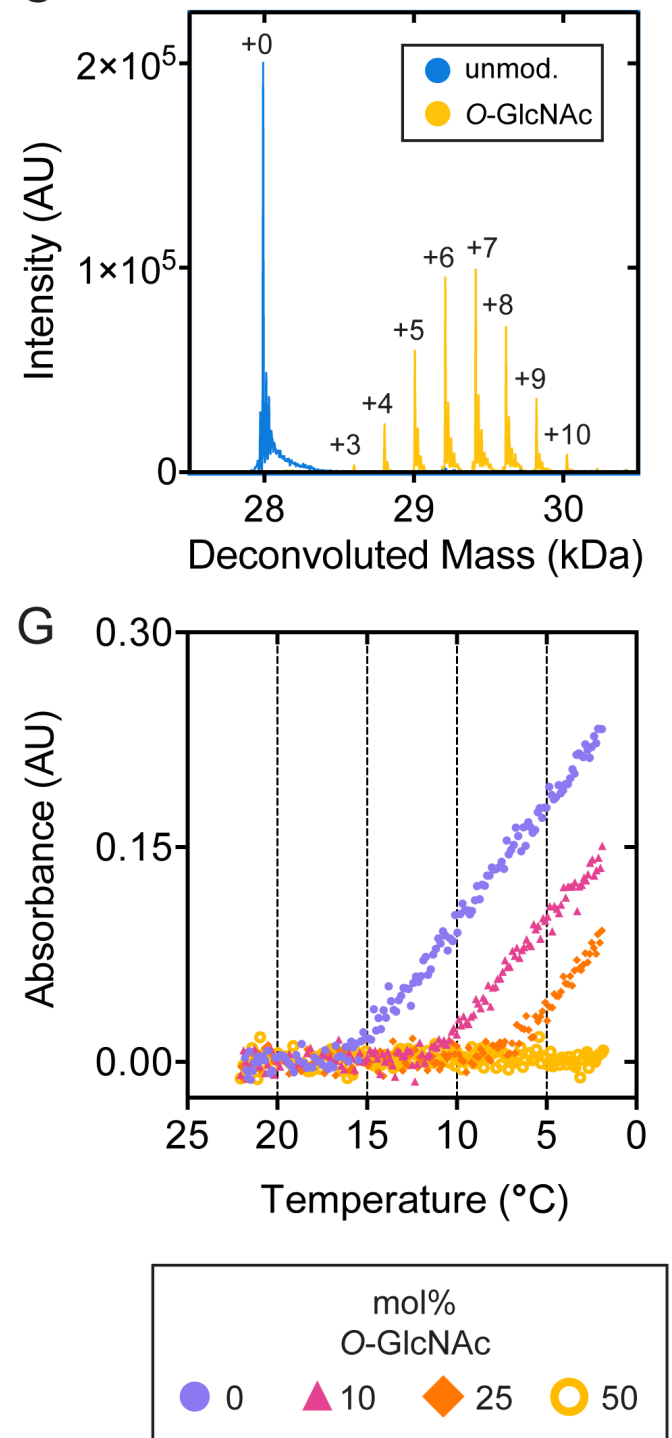

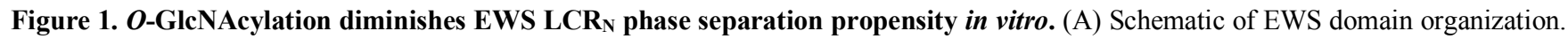
PLD, prion-like domain low-complexity disordered region; RGG, arginine-glycine-glycine rich low-complexity disordered region; RRM, RNA-recognition motif; ZnF, zinc finger. (B) Schematic of the OGT-catalyzed $O$-GlcNAcylation of serine and threonine sidechains. (C) Deconvoluted mass spectra corresponding to unmodified (blue) and $O$-GlcNAcylated (yellow) LCR $\mathrm{L}_{\mathrm{N}}$ Labels indicate number of $O$ GlcNAc modifications. (D) Differential interference contrast (DIC) micrographs of $30 \mu \mathrm{M}$ unmodified (top) or $O$-GlcNAcylated (bottom) EWS LCR $\mathrm{N}_{\mathrm{N}}$ in $25 \mathrm{mM}$ Tris $\mathrm{pH} 7.5$ at lab temperature with denoted $\mathrm{NaCl}$ concentrations. Scale: $20 \mu \mathrm{m}$. (E,F) Salt and concentration condi-

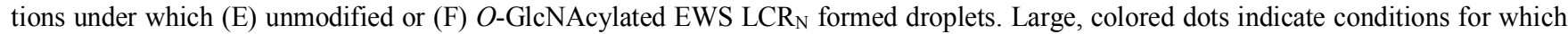
droplets were observed; small black dots indicate an absence of droplets. $(\mathrm{G})$ Temperature-dependent turbidity $(\lambda=500 \mathrm{~nm})$ of LCR $\mathrm{N}_{\mathrm{N}}$ samples containing variable proportions of $O$-GlcNAcylated $\mathrm{LCR}_{\mathrm{N}}$. Total LCR $\mathrm{L}_{\mathrm{N}}$ concentration is consistently $30 \mu \mathrm{M}$; legend indicates the proportion of $O$-GlcNAcylated $\mathrm{LCR}_{\mathrm{N}}$ present in the samples.

diamond). At a 1:1 ratio of $O$-GlcNAcylated:unmodified $\mathrm{LCR}_{\mathrm{N}}$, turbidity was absent at all points of the temperature series under these conditions (Figure $1 \mathrm{G}$ ring). Thus, $O$ GlcNAcylation reduces the propensity of EWS $\mathrm{LCR}_{\mathrm{N}}$ to phase separate in response to increasing salt concentrations and decreasing temperature.
To determine if phase behavior correlates with the number of $O$-GlcNAc modifications, we prepared small-scale $O$ GlcNAcylation reactions containing the EWS $\mathrm{LCR}_{\mathrm{N}}$ and varying concentrations of OGT. Following a 30-minute reaction period, the $\mathrm{NaCl}$ concentration was adjusted to $200 \mathrm{mM}$ 
bioRxiv preprint doi: https://doi.org/10.1101/2021.05.11.443654; this version posted May 11, 2021. The copyright holder for this preprint (which was not certified by peer review) is the author/funder, who has granted bioRxiv a license to display the preprint in perpetuity. It is made

A

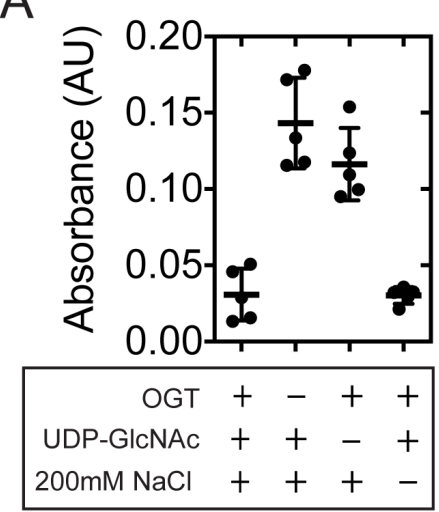
available under aCC-BY-NC 4.0 International license.

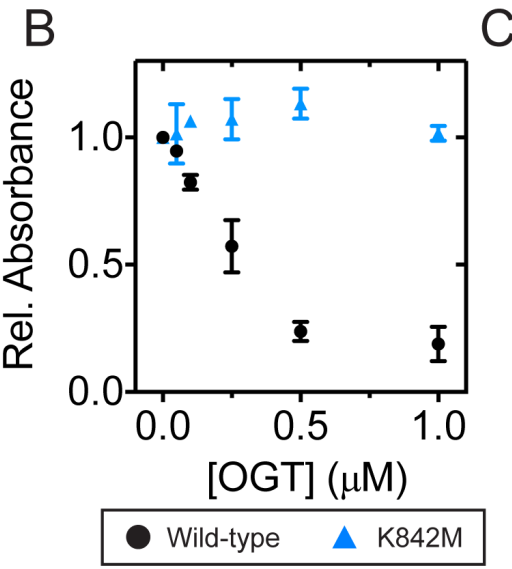

$\mathrm{C}$
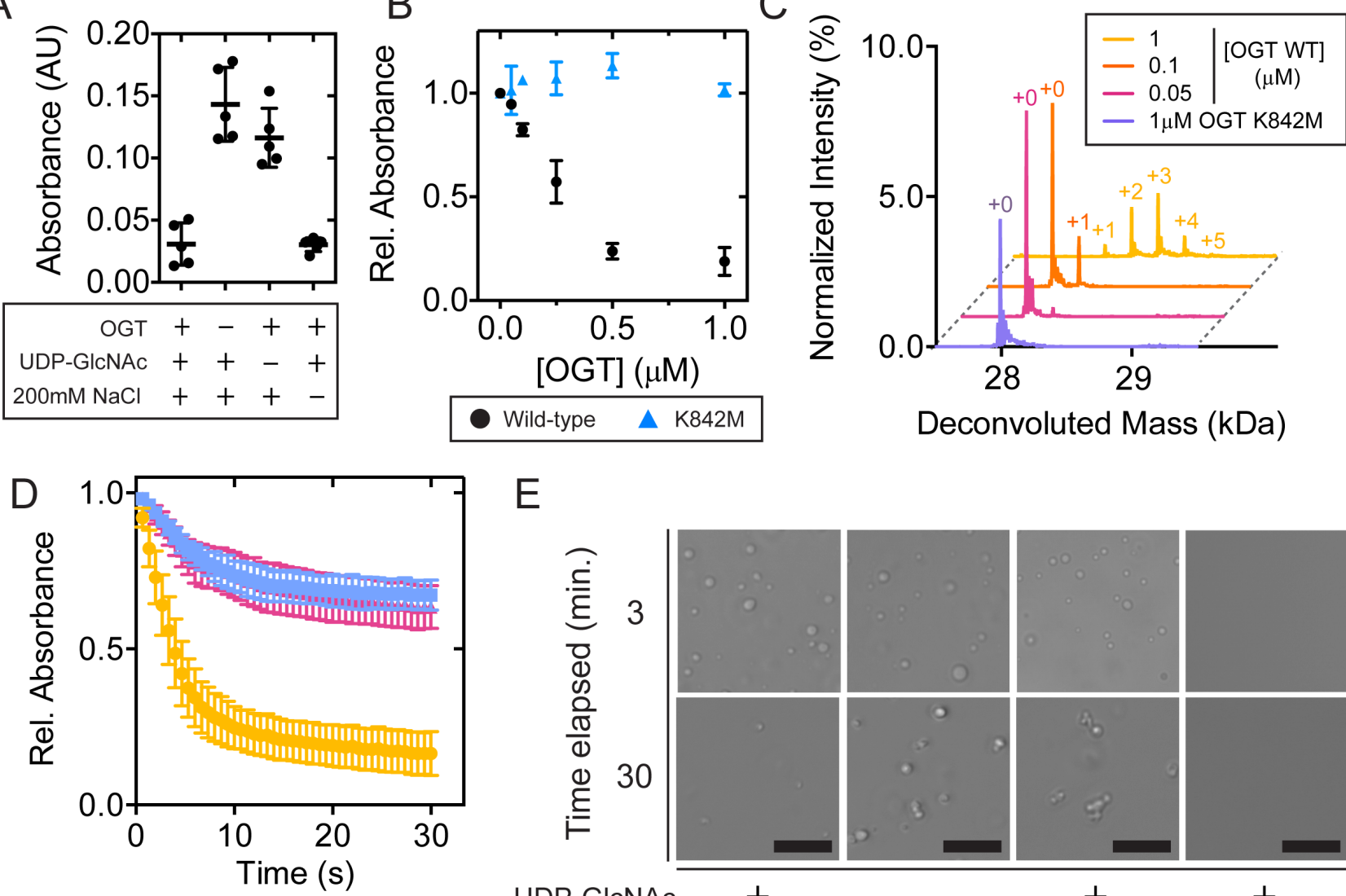

E

\begin{tabular}{|rccc|}
\hline UDP-GICNAC & + & - & + \\
OGT & + & + & - \\
\hline
\end{tabular}

UDP-GICNAC

OGT
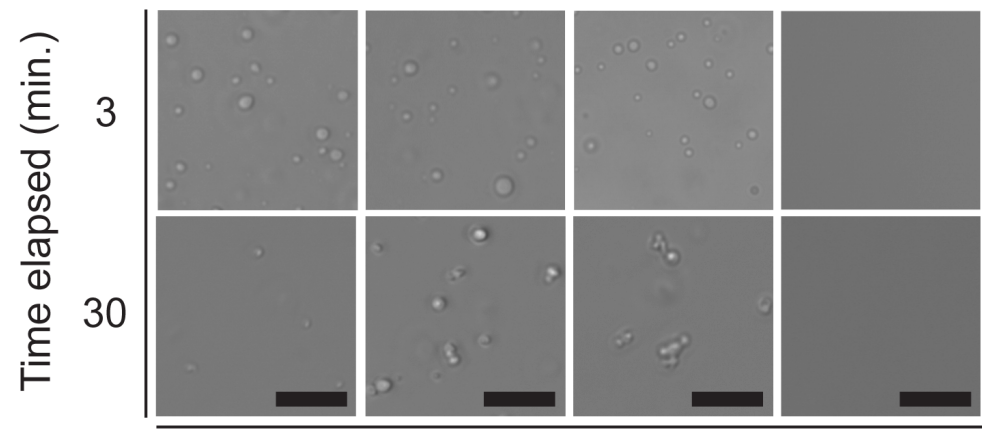

Figure 2. EWS LCR $\mathbf{L}_{\mathbf{N}}$ phase separation propensity is reduced as $\boldsymbol{O}$-GIcNAc modifications increase. (A) Turbidity $(\lambda=500 \mathrm{~nm})$ of $\operatorname{LCR}_{\mathrm{N}}(20 \mu \mathrm{M}) O$-GlcNAcylation reaction samples following addition of $\mathrm{NaCl}$. Central bold bars represent mean, with error bars showing standard deviation, $\mathrm{n}=5$. (B) Relative turbidity $(\lambda=500 \mathrm{~nm})$ of $\mathrm{LCR}_{\mathrm{N}}(20 \mu \mathrm{M}) O$-GlcNAcylation reactions as a function of varying OGT wild-type (black) or K842M (blue) concentration. Droplet formation was induced by addition of NaCl following a 30-minute reaction period. Error bars represent standard deviation, $\mathrm{n}=3$. (C) LC-ESI MS analysis of samples in (B). (D) Relative turbidity $(\lambda=500 \mathrm{~nm})$ of $\mathrm{LCR}_{\mathrm{N}} O$-GlcNAcylation reactions containing phase-separated EWS LCR $(20 \mu \mathrm{M})$ as a function of reaction time. Errors bars represent standard deviation, $\mathrm{n}=5$. (E) DIC micrographs corresponding to samples in (D) at 3 or 30 minutes post-addition of UDP-GlcNAc. Scale: $20 \mu \mathrm{m}$. Unless stated otherwise, OGT and UDP-GlcNAc concentrations in each reaction were $1 \mu \mathrm{M}$ and $1 \mathrm{mM}$, respectively.

to promote droplet formation, which we measured by turbidity. EWS LCR samples displayed an approximately sixfold increase in turbidity following the addition of $\mathrm{NaCl}$ (Figure 2A). Inclusion of both OGT and UDP-GlcNAc resulted in no turbidity change at 30 minutes relative to samples kept at low $(50 \mathrm{mM}) \mathrm{NaCl}$ (Figure 2A). The relative turbidity scaled inversely with the number of $O$-GlcNAc modifications (Figure 2B,C). Substituting wild-type OGT with the catalytically-deficient mutant (K842M) did not produce any changes in turbidity with respect to enzyme concentration (Figure 2B), meaning that the reduction in turbidity seen with wild-type was not merely caused by enzyme binding-induced solubilization of the $\mathrm{LCR}_{\mathrm{N}}$. Even the lowest tested OGT concentrations $(0.05,0.1 \mu \mathrm{M})$ resulted in slight reductions in turbidity, despite only a minor fraction of $\mathrm{LCR}_{\mathrm{N}}$ molecules being $O$-GlcNAcylated under these condi- tions (Figure 2C). These data suggest that $O$-GlcNAcylation lessens salt-induced phase separation of the EWS $L_{C R}$ even at sub-stoichiometric modification levels. We then asked whether the $\mathrm{LCR}_{\mathrm{N}}$ can be $O$-GlcNAcylated in the condensed phase after phase separation, and if so, will $O$ GlcNAcylation cause the droplets to disassemble. We performed turbidity assays in which $\mathrm{LCR}_{\mathrm{N}}$ phase separation was induced with $200 \mathrm{mM} \mathrm{NaCl}$ prior to the onset of $O$ GlcNAcylation. Following a 30-minute reaction period, LCR $_{N}$ samples containing OGT and UDP-GlcNAc yielded similar modification patterns to those for reactions per formed in the dilute phase (Figure S1E). All samples, including those lacking either OGT or UDP-GlcNAc, displayed time-dependent decreases in turbidity due to the droplets sinking. However, the samples containing both OGT and 

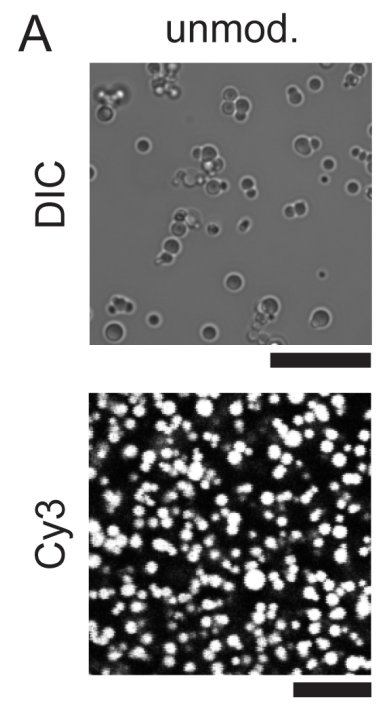

\section{O-GIcNAc}
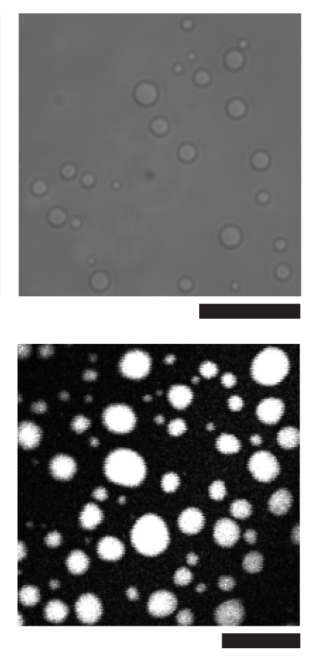

B
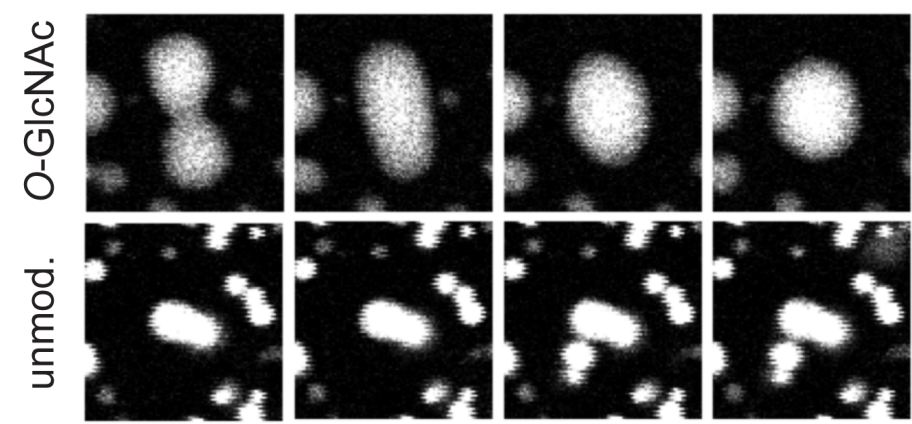

time $(\mathrm{s})$

0
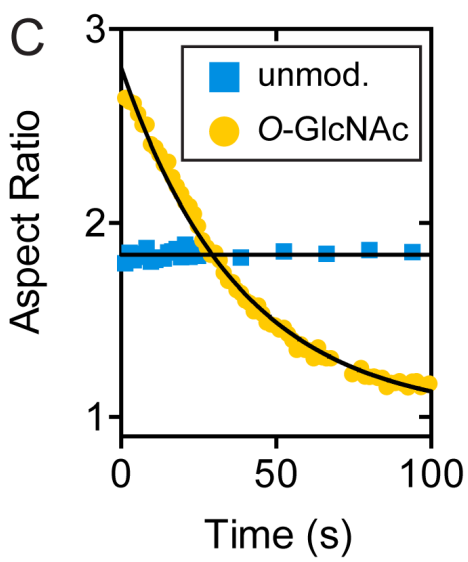

15

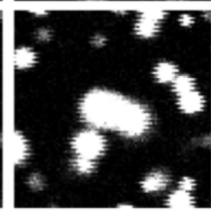

30

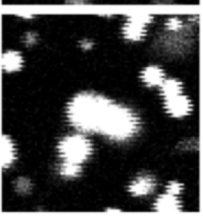

45

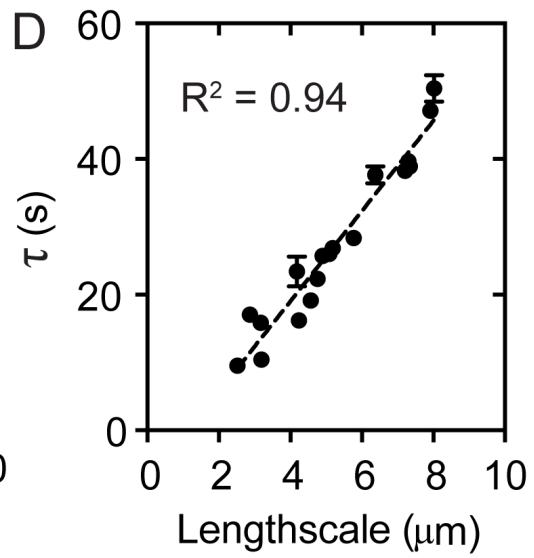

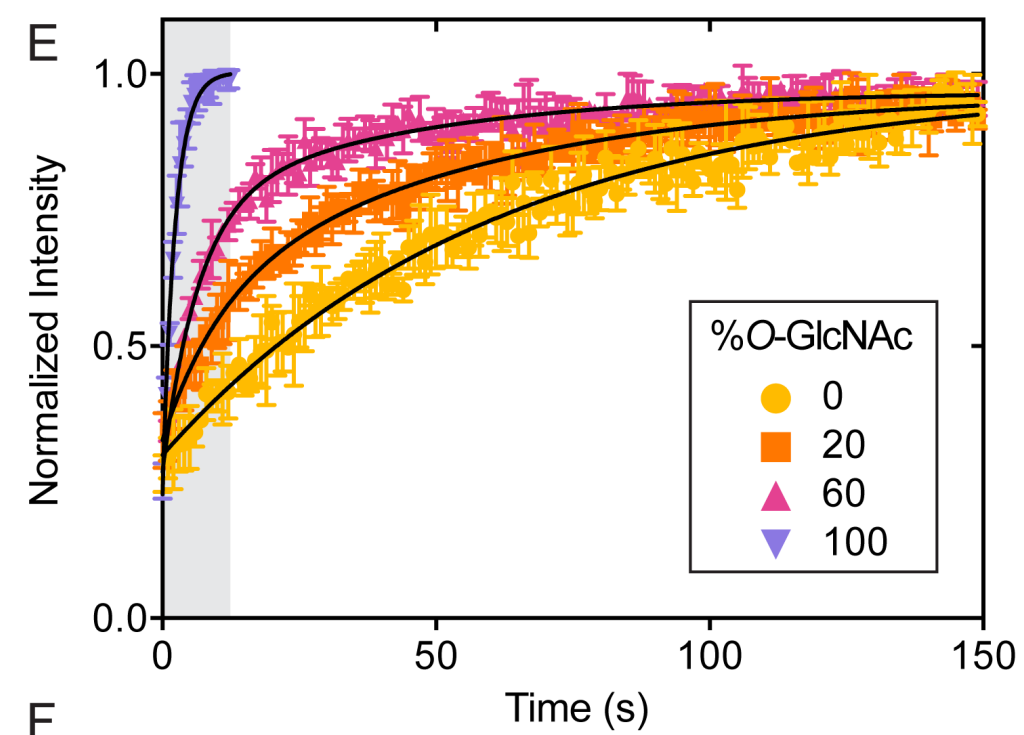

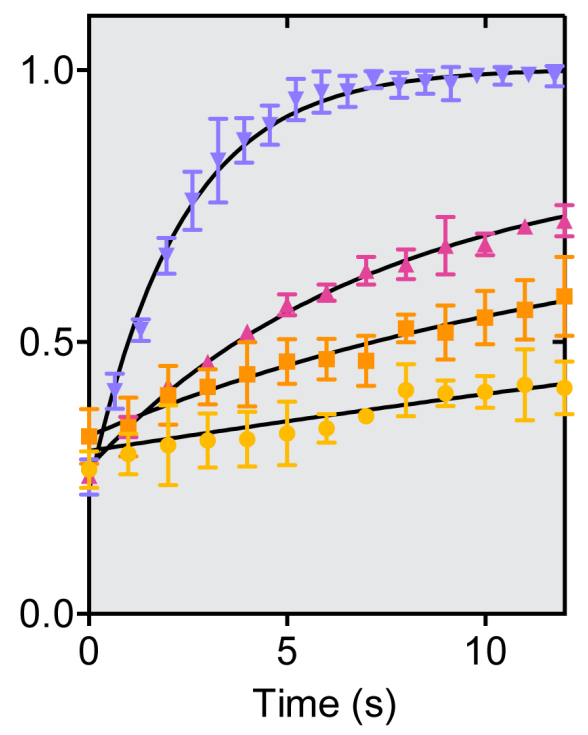

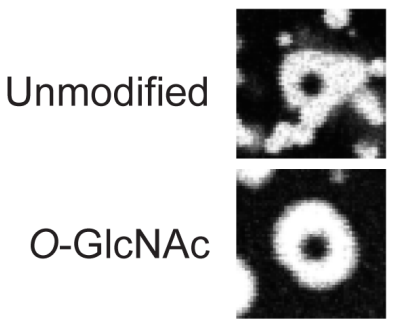

(s)

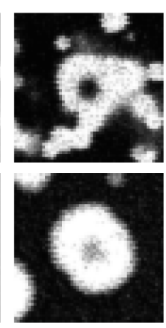

3.9

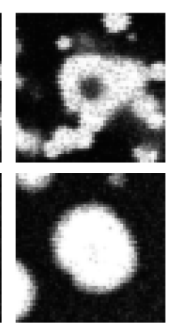

7.8

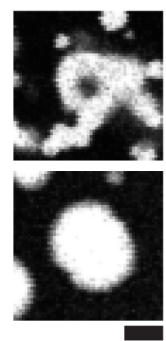

11.7

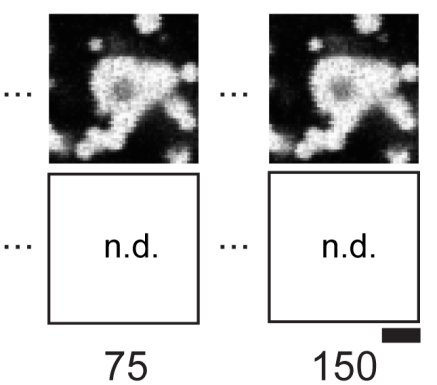

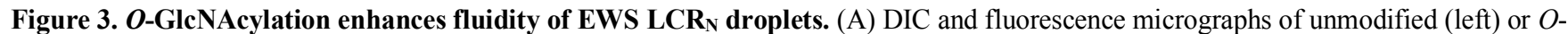
GlcNAcylated (right) $\mathrm{LCR}_{\mathrm{N}}$ droplets. Droplets spiked with $100 \mathrm{nM}$ sulfo-Cy3-labelled $\mathrm{LCR}_{\mathrm{N}}$ (with or without $O$-GlcNAcylation) were imaged at $30 \mathrm{~min}$. (middle) or $90 \mathrm{~min}$. (bottom) post-formation. Both samples contain $30 \mu \mathrm{M}$ total protein concentration, in $25 \mathrm{mM}$ Tris, $500 \mathrm{mM} \mathrm{NaCl}, \mathrm{pH} 7.5$ at lab temperature. Scale: $20 \mu \mathrm{m}$. (B) Time lapse images of unmodified (bottom) and $O$-GlcNAcylated (top) sulfo- 
bioRxiv preprint doi: https://doi.org/10.1101/2021.05.11.443654; this version posted May 11, 2021. The copyright holder for this preprint (which was not certified by peer review) is the author/funder, who has granted bioRxiv a license to display the preprint in perpetuity. It is made available under aCC-BY-NC 4.0 International license.

Cy3-spiked $\mathrm{LCR}_{\mathrm{N}}$ droplets fusing (same conditions as in (A)). Scale: $5 \mu \mathrm{m}$. (C) Plot of droplet aspect ratio versus time for representative fusion events displayed in (B). (D) Time constants $(\tau)$ of exponentially decaying $O$-GlcNAcylated droplet aspect ratio versus length scale (distance between fusing droplets). The slope of the linear fit estimates the inverse capillary velocity (ratio of effective droplet viscosity to surface tension): $\sim 6.6 \mu \mathrm{m} \mathrm{s}^{-1}$. Error bars represent the SEM of fitted $\tau$ values. (E) FRAP traces from droplets containing variable ratios of

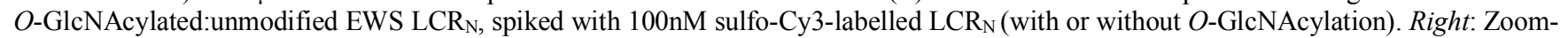
in of grey shaded area in left panel. $\mathrm{N}=4$; error bars represent standard deviation. (F) Fluorescence micrographs of representative FRAP time points in (E). n.d.: no data. Scale: $5 \mu \mathrm{m}$.

UDP-GlcNAc underwent a significantly greater decrease over the 30-minute time course, after which few droplets could be observed by microscopy (Figure 2D,E). Samples lacking either OGT or UDP-GlcNAc contained droplets before and after the reaction period (Figure 2D,E). Interestingly, we never witnessed total clearance of the droplets, perhaps because levels of $O$-GlcNAcylation were generally lower than when the $\mathrm{LCR}_{\mathrm{N}}$ was modified in the dilute state (Figure S1E). This could have resulted from the nonmutually exclusive possibilities of OGT having lower catalytic turnover rates in the presence of $200 \mathrm{mM} \mathrm{NaCl}$ or in the droplets, or from its lower partitioning into the condensed phase. These data demonstrate that $O$-GlcNAcylation can effectively reverse EWS $\mathrm{LCR}_{\mathrm{N}}$ droplet formation in vitro.

We then examined how $O$-GlcNAcylation affects the morphologies of EWS $\mathrm{LCR}_{\mathrm{N}}$ droplets over time. Within minutes after formation, the unmodified $\mathrm{LCR}_{\mathrm{N}}$ droplets cluster into bleb-like structures with irregular boundaries, whereas the $O$-GlcNAcylated droplets merge into larger, circular droplets with smooth boundaries (Figure 3A). To test if the $O$-GlcNAc-dependent morphological differences were caused by changes in the droplets' material properties, we measured the impact of $O$-GlcNAc on droplet fusion, which is a diagnostic characteristic of liquid-like behavior in protein condensates. We prepared samples of the unmodified and $O$-GlcNAcylated $\mathrm{LCR}_{\mathrm{N}}$ droplets spiked with $100 \mathrm{nM}$ $(\sim 0.3 \mathrm{~mol} \%$ ) sulfo-cyanine-3 (sulfo-Cy3)-labelled protein for visualization by scanning confocal fluorescence microscopy (Figure 3A). After colliding, $O$-GlcNAcylated droplets spontaneously merged and relaxed into circular shapes when viewed along the xy-plane, tending to a unitary aspect ratio within seconds to minutes (Figure 3B,C). The unmodified droplets adhered upon collision but did not deform, instead retaining their pre-fusion morphologies. For the $O$ GlcNAcylated droplets, the exponential decay in aspect ratio was linearly proportional to the length scale of the fusion event, consistent with previously reported behavior of liquidlike protein condensates in vitro (Figure 3D) ${ }^{59}$. $\mathrm{O}$ GlcNAcylated EWS $\mathrm{LCR}_{\mathrm{N}}$ droplets fuse more slowly than other in vitro protein condensates such as those formed by NPM1 46 , LAF-1 ${ }^{60}$ or PR $_{60}$-repeat peptides with RNA ${ }^{61}$, perhaps indicating higher viscosity or surface tension, though the comparison may be skewed by differences in sample conditions.

To determine whether the diffusion of $\mathrm{LCR}_{\mathrm{N}}$ molecules within droplets is affected by $O$-GlcNAcylation, we performed fluorescence recovery after photobleaching (FRAP) measurements on the same sulfo-Cy3-spiked droplet samples. Within the unmodified droplets, fluorescence intensity returned to $\sim 90 \%$ of pre-bleach levels within a $2.5 \mu \mathrm{m}$ diameter photobleached region in under 3 minutes (Figure $3 \mathrm{E}, \mathrm{F})$, indicating that the majority of molecules remain mo- bile despite the droplets' inability to fuse. Applying the same photobleaching parameters onto the $O$-GlcNAcylated $\mathrm{LCR}_{\mathrm{N}}$ droplets resulted in similar levels of fluorescence recovery on a significantly reduced time scale (Figure 3E,F). Fitting a monophasic exponential model to these data gave fluorescence recovery half-times of $41.6 \pm 1.7 \mathrm{~s}$ and $1.59 \pm 0.07 \mathrm{~s}$ for the unmodified and $O$-GlcNAcylated droplets, respectively. In droplets containing mixed ratios of O-GlcNAcylated and unmodified $\mathrm{LCR}_{\mathrm{N}}$, the recovery half-times decreased proportionally with the amount of $O$-GlcNAcylated $\mathrm{LCR}_{\mathrm{N}}$ present (Figure $3 \mathrm{E}$ ). We cannot confidently estimate diffusion coefficients from these data due to the dissimilar sizes of the differentially modified droplets as well as the potential flaws in using a single-exponential model to describe the underlying diffusion mechanisms ${ }^{62}$. However, the difference in half-times is striking, clearly demonstrating that $O$ GlcNAcylation enhances diffusion of EWS LCR $\mathrm{N}_{\mathrm{N}}$ molecules within condensates. Based on the disparate fusion behaviors and accelerated FRAP, we suggest that $O$-GlcNAcylation enhances the liquidity of EWS $\mathrm{LCR}_{\mathrm{N}}$ droplets, which are otherwise highly viscous or perhaps gel-like in the absence of this modification.

FET protein phase separation is not solely driven by $\mathrm{LCR}_{\mathrm{N}}$ self-interactions; rather, the tyrosine-rich $\mathrm{LCR}_{\mathrm{N}}$ and arginine-rich RBDs synergistically promote phase separation 9,50 , 63 . Thus, we sought to determine if $O$-GlcNAcylation would impact co-phase separation of these two regions of EWS (Figure 1A). We titrated the EWS $\mathrm{LCR}_{\mathrm{N}}$ with or without $O$ GlcNAcylation into samples of the EWS RBD under lowsalt buffer conditions in which neither would phase separate on its own. Turbidity increased proportionally with the concentration of unmodified $\mathrm{LCR}_{\mathrm{N}}$ and coincided with the presence of droplets (Figure 4A,B). We saw a similar increase as we titrated the $O$-GlcNAcylated $\mathrm{LCR}_{\mathrm{N}}$, however, the onset of turbidity occurred at a higher $\mathrm{LCR}_{\mathrm{N}}$ concentration, indicating lower phase separation propensity (Figure 4A,B). This effect was more pronounced when the level of $O$ GlcNAcylation was increased, supporting a direct link between $O$-GlcNAc levels and RBD-dependent droplet formation. As a point of comparison, we also tested the effect of asymmetric dimethylation of the RBD arginines (another PTM shown to mitigate phase separation of FUS ${ }^{52,63}$ ) under the same conditions, finding that the increase in saturation concentration was approximately the same as that caused by $\mathrm{LCR}_{\mathrm{N}} O$-GlcNAcylation (Figure 4A).

We then tested the effect of $\mathrm{LCR}_{\mathrm{N}} O$-GlcNAcylation on the diffusive characteristics of droplets containing both the $\mathrm{LCR}_{\mathrm{N}}$ and RBD (LCR + RBD droplets), spiked with sulfoCy3-LCR ${ }_{N}$. Interestingly, the unmodified $\mathrm{LCR}_{\mathrm{N}}+\mathrm{RBD}$ droplets exhibited more rapid fluorescence recovery than the unmodified $\mathrm{LCR}_{\mathrm{N}}$ droplets without addition of the RBD 4C). 
bioRxiv preprint doi: https://doi.org/10.1101/2021.05.11.443654; this version posted May 11, 2021. The copyright holder for this preprint (which was not certified by peer review) is the author/funder, who has granted bioRxiv a license to display the preprint in perpetuity. It is made available under aCC-BY-NC 4.0 International license.
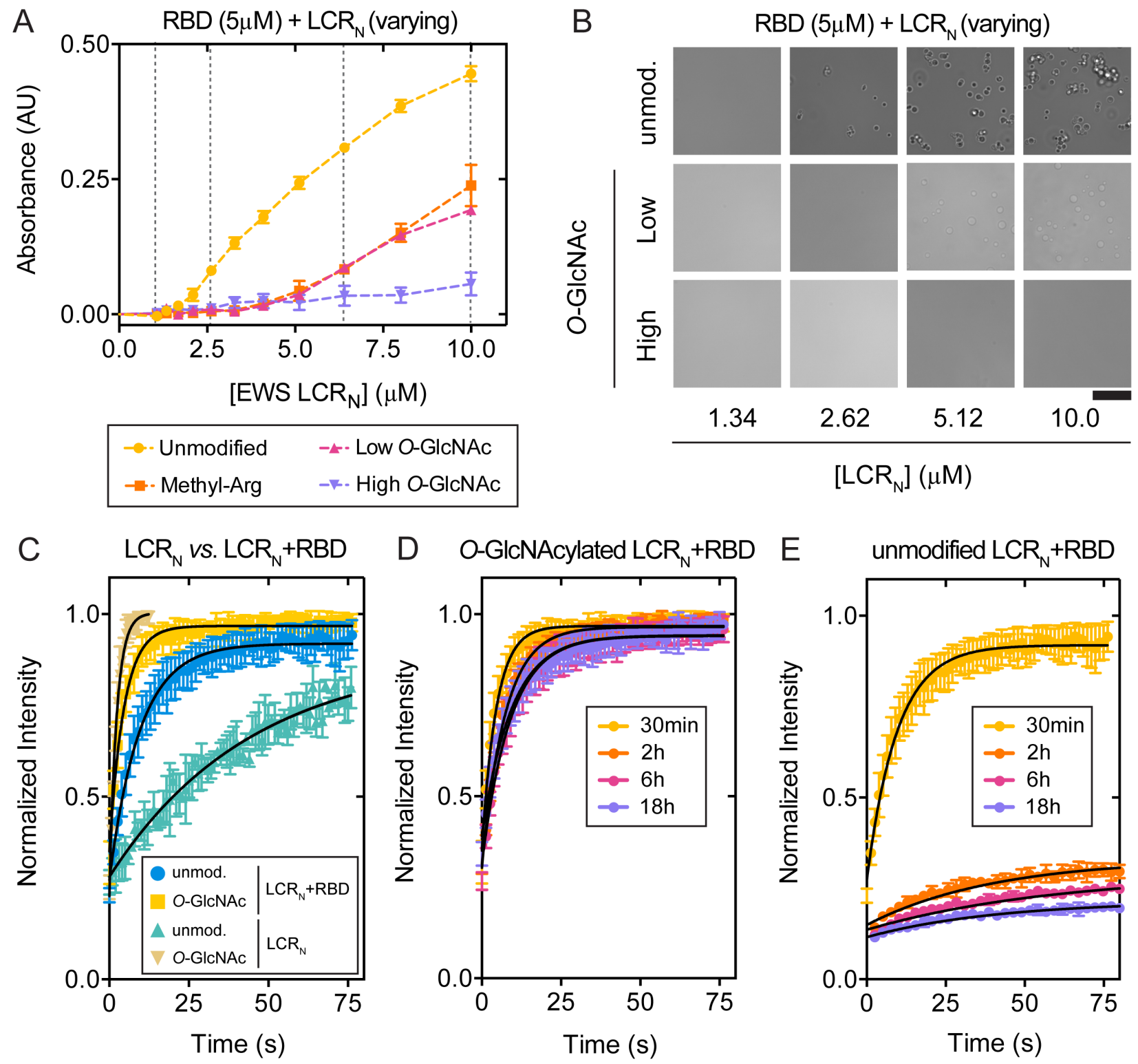

Figure 4. EWS LCR $O$-GlcNAcylation reduces RBD-induced phase separation and prevents time-dependent loss of droplet dynamics. (A) Turbidity $(\lambda=500 \mathrm{~nm})$ of EWS RBD samples $\left(5 \mu \mathrm{M}\right.$; with or without arginine methylation) titrated with LCR $\mathrm{L}_{\mathrm{N}}$ (with or without $O$ GlcNAcylation) in $25 \mathrm{mM}$ Tris, $100 \mathrm{mM} \mathrm{NaCl}, 0.5 \mathrm{mM}$ tetrasodium EDTA, $2 \mathrm{mM}$ dithiothreitol, $\mathrm{pH} 7.5$ at $25^{\circ} \mathrm{C}$. Turbidity was measured immediately after mixing of the two EWS fragments. Error bars represent standard deviation, $n=3$. (B) DIC micrographs of samples in (A) indicated by hatched vertical lines. Scale: $20 \mu \mathrm{m}$. (C) FRAP traces for EWS $\mathrm{LCR}_{\mathrm{N}}$ and $\mathrm{LCR}_{\mathrm{N}}+\mathrm{RBD}$ droplets with and without LCR $O$-GlcNAcylation. $\mathrm{LCR}_{\mathrm{N}}$ droplet samples are the same as in $(3 \mathrm{E}) . \mathrm{LCR}_{\mathrm{N}}+\mathrm{RBD}$ droplet samples contain $10 \mu \mathrm{M}$ LCR , $100 \mathrm{nM}$ sulfo-Cy3labelled $\mathrm{LCR}_{\mathrm{N}}, 10 \mu \mathrm{M}$ RBD, $25 \mathrm{mM}$ Tris, $100 \mathrm{mM} \mathrm{NaCl}, 0.5 \mathrm{mM}$ tetrasodium EDTA, 2mM dithiothreitol, $\mathrm{pH} 7.5$ at lab temperature. (D) FRAP traces of $O$-GlcNAcylated and (E) unmodified $\mathrm{LCR}_{\mathrm{N}}+\mathrm{RBD}$ droplets measured at different time points following phase separation under the same conditions as (C). Error bars represent standard deviation, $n=3$. Black lines are single exponential fits.

While the FRAP kinetics of the unmodified and $O$ GlcNAcylated $\mathrm{LCR}_{\mathrm{N}}+\mathrm{RBD}$ droplets were similar within 30minutes following phase separation, they began to diverge at later time points (Figure 4D,E). O-GlcNAcylated $\mathrm{LCR}_{\mathrm{N}}+\mathrm{RBD}$ droplets exhibited near-complete fluorescence recovery irrespective of the incubation time (Figure 4D,S2), whereas the unmodified droplets already showed decreasing fluorescence recovery at 2 hours post-formation (Figure 4E,S2). The mobile fraction in the unmodified $\mathrm{LCR}_{\mathrm{N}}+\mathrm{RBD}$ droplets decreased even further at later timepoints, reaching only $\sim 10 \%$ after 18 hours. These results suggest that mole- cules within the droplets containing the unmodified $\mathrm{LCR}_{\mathrm{N}}$ lose the ability to diffuse in a time-dependent fashion indicating a progression to a less fluid-like material state. $O$ GlcNAcylation prevents this loss of mobility, instead maintaining the liquid-like droplet dynamics that are seen shortly after phase separation.

Based on our observations in vitro, we investigated the effect of $O$-GlcNAcylation on EWS aggregation propensity in cells. We used a filter retardation assay (FRA) to monitor EWS aggregation in HeLa cells following changes in $O$ - 
bioRxiv preprint doi: https://doi.org/10.1101/2021.05.11.443654; this version posted May 11, 2021. The copyright holder for this preprint (which was not certified by peer review) is the author/funder, who has granted bioRxiv a license to display the preprint in perpetuity. It is made

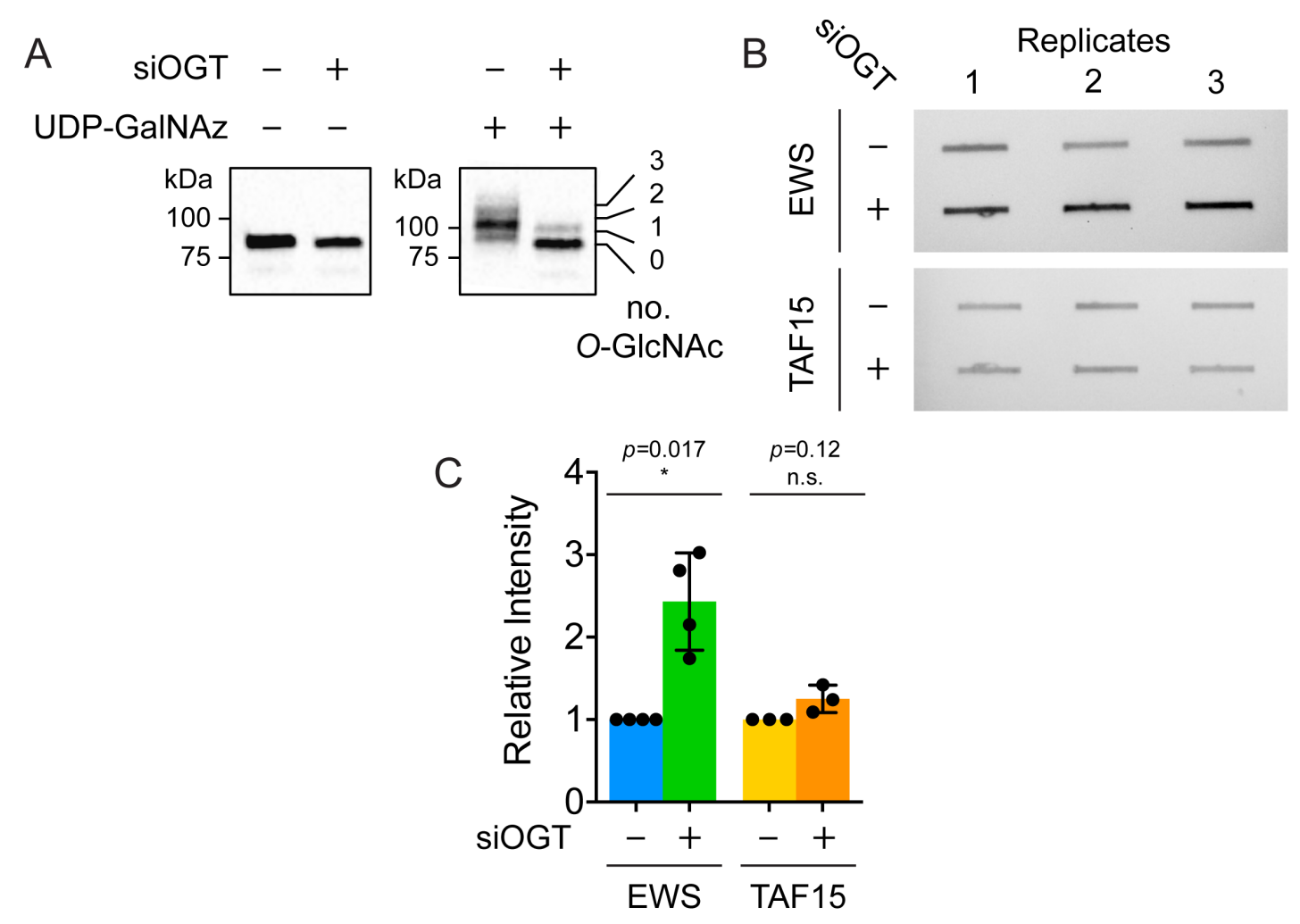

Figure 5. $\boldsymbol{O}$-GIcNAcylation decreases EWS aggregation in HeLa cell lysates. (A) Western blot (anti-EWS) depicting chemoenzymatic (ClickIT) labelling of $O$-GlcNAc moieties on EWS isolated from HeLa cells, treated with or without siOGT (48-hour incubation with $20 \mathrm{nM}$ small interfering RNA for OGT). GlcNAc moieties are enzymatically modified with uridine-diphospho- $N$-azidoacetylgalactosamine (UDP-GalNAz) and then alkynyl-PEG (average molecular weight: $5 \mathrm{kDa}$ ) via Huisgen cycloaddition ('Click' chemistry) to produce an apparent molecular weight shift of $\sim 5 \mathrm{kDa}$ per GlcNAc moiety via SDS-PAGE. (B) Representative images of FRA membranes following Western blot detection of EWS (top) or TAF15 (bottom), with and without siOGT treatment. (C) Normalized EWS and TAF15 Western blot intensities from three FRA replicates performed with OGT-depleted HeLa cell lysates. Error bars represent standard deviation. For EWS: $p=0.017$, Student's $t$-test; $\mathrm{n}=4$. For TAF15: $p=0.12$, Student's $t$-test; $\mathrm{n}=3$.

GlcNAcylation levels. In this assay, large $(>0.2 \mu \mathrm{m})$ sodium dodecyl sulfate (SDS)-insoluble protein aggregates are captured by vacuum filtration on a cellulose-acetate membrane, while smaller protein assemblies and monomers pass through. The captured aggregates are subsequently detected by immunoblotting. To modulate $O$-GlcNAcylation levels, we downregulated OGT expression using small interfering RNA (siOGT), which caused a global reduction in $O$ GlcNAcylation levels (Figure S3A) including reduction in $O$-GlcNAcylation of EWS as measured by chemoenzymatic labeling (Figure 5A). We found that siOGT treatment led to increased EWS aggregation signal in the FRA versus untreated control samples (Figure 5B,C). In contrast, TAF15, another FET family member that is known to phase separate and/or aggregate ${ }^{36,50,64}$ but is not $O$-GlcNAcylated 54 (Figure $\mathrm{S} 3 \mathrm{~B}$ ), did not experience greater aggregation following siOGT treatment (Figure 5B,C). This suggests that the increased EWS aggregation is a direct consequence of its $O$ GlcNAcylation status rather than a global, proteinnonspecific aggregation caused by decreasing $O$ GlcNAcylation levels. OGT knockdown did not significantly affect the expression levels of EWS or TAF15 (Figure S3C), which could contribute to either protein's aggregation. Taken together, these results show that the aggregation propensity of EWS is directly correlated with its $O$-GlcNAcylation status in cells.
Supposing that $O$-GlcNAcylation might be used by the cell to inhibit aggregation of some phase-separating proteins, we then asked if $O$-GlcNAcylation is generally correlated with higher phase separation propensity. We performed a bioinformatic analysis to calculate the percentage of $O$ GlcNAcylated human proteins predicted to phase separate by three metrics, PScore ${ }^{9}$, catGRANULE ${ }^{65}$ and PLAAC ${ }^{66,67}$, compared to that for all post-translationally modified proteins included in the PhosphoSitePlus PTM database and the entire human proteome. $O$-GlcNAcylated proteins show a significant enrichment for increased phase separation propensity for each of the three metrics as defined by the fraction scoring above each predictor's preestablished threshold (Figure S4A). To account for differences in the number of proteins above each predictor's cut-off, we also compared the fractions that scored in the top 4th percentile, finding that the enrichment in $O$-GlcNAcylated proteins remains consistent (Figure 6). The significant enrichment also persists across the metrics when querying for proteins with long ( $>100$ residue) IDRs (Figure S4B), indicating that the potentially greater proportion of $O$-GlcNAc site annotations being present in long IDRs and the greater proportion of phaseseparating proteins having long IDRs does not affect this finding. These results suggest that phase- separating proteins are more likely to be subject to $O$-GlcNAc-mediated regulation than the proteome in general. PLAAC, which predicts 
bioRxiv preprint doi: https://doi.org/10.1101/2021.05.11.443654; this version posted May 11, 2021. The copyright holder for this preprint (which was not certified by peer review) is the author/funder, who has granted bioRxiv a license to display the preprint in perpetuity. It is made available under aCC-BY-NC 4.0 International license.

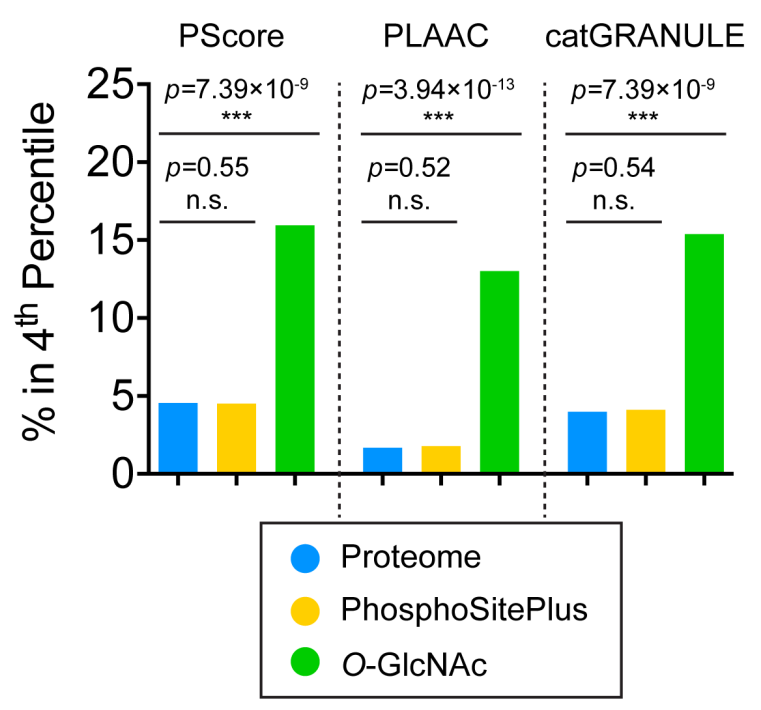

Figure 6. O-GlcNAcylated proteins are enriched for predicted phase separation propensity. Comparison of proteins scoring in the top $4^{\text {th }}$ percentile of the proteome by three different metrics of phase separation propensity (PScore, PLAAC and catGRANULE). Protein sequences for the human proteome were retrieved from the Uniprot database $(\mathrm{n}=21047$, blue). The human proteins with documented posttranslational modifications $(\mathrm{n}=19990$, yellow) and those modified through $O$-GlcNAcylation $(\mathrm{n}=171$, green $)$ were retrieved from the PhosphoSitePlus database. The $O$-GlcNAcylated proteins show a significant enrichment for increased phase separation propensity relative to the proteome and post-translationally modified human proteins for each of the three metrics. Indicated $p$-values were derived from Fisher's exact test.

protein regions with prion-like sequence compositional bias ${ }^{66}$, showed the greatest statistical enrichment of the three metrics, implying that $O$-GlcNAcylation may be especially relevant for PLD-containing, phase-separating proteins that are prone to aggregation.

\section{DISCUSSION}

We examined the effects of $O$-GlcNAc, a widespread PTM with diverse functional consequences ${ }^{11,15,16}$, on the phase separation and material properties of EWS condensates. $O$-GlcNAcylated $\mathrm{LCR}_{\mathrm{N}}$ requires higher protein and salt concentrations and lower temperatures to form droplets, evidence for a decreased phase separation propensity. $O$ GlcNAcylated EWS droplets are more fluid than unmodified droplets based on their increased relaxation to spherical shapes following fusion and their more rapid FRAP. Inclusion of the EWS RBD in trans promotes fluidity at short times, although the internal mobility of $\mathrm{LCR}_{N}+\mathrm{RBD}$ droplets diminishes as the unmodified droplets age, perhaps due to a time-dependent increase in PLD-induced cross-beta structure 33. This transition does not occur when the $\mathrm{LCR}_{\mathrm{N}}$ is $O$ GlcNAcylated, suggesting that $O$-GlcNAc preserves fluidlike condensate dynamics over time.

The effects of $O$-GlcNAcylation on the assembly and dynamics of higher-order protein complexes has already been described in several systems, including FG-Nup hydrogels ${ }^{22}$, Drosophila Polycomb complexes ${ }^{21}$, intermediate filaments ${ }^{68}$, and pathological fibrillar aggregates formed by tau and alpha-synuclein ${ }^{23-25}$. In each of these cases, $O$ GlcNAcylation tends to promote protein solubility by sterically disrupting intermolecular interactions between monomers. Our results suggest that the same effect may apply to EWS $\mathrm{LCR}_{\mathrm{N}}$ condensates, whose phase separation and liquidlike dynamics are sensitive to the strengths and numbers of
$O$-GlcNAc-modulated intermolecular interactions. We demonstrate that $O$-GlcNAc modulates EWS condensate dynamics even at sub-stoichiometric levels, meaning that not all molecules within the condensate must be modified in order for bulk condensate properties to be affected. These results mirror previous findings that sub-stoichiometric $O$ GlcNAcylation slows formation of alpha-synuclein fibrils ${ }^{23}$. Thus, $O$-GlcNAcylation may influence condensate properties even when the modified species are not the most abundant components of the system.

Interactions between tyrosine and arginine residues are significant drivers of phase separation of PLD-containing RNA-binding proteins such as EWS ${ }^{50}$. $O$-GlcNAc reduces phase separation of the tyrosine-rich EWS LCRN together with the arginine-rich RBD, suggesting that it can affect their interactions even though neither of these key residue types ${ }^{50}$ are directly modified. The sugar may sterically block cohesive interactions important for phase separation and aggregation, including those underlying cross-beta structures ${ }^{40}$. In addition to these steric effects, $O$-GlcNAc-mediated changes in intermolecular interactions could also derive from bulk changes in the chemical properties of the LCRN. $O$-GlcNAc is uncharged, unlike phosphorylation - to which $O$-GlcNAc is often compared and which is potentially reciprocally regulated ${ }^{69}$. Thus, $O$-GlcNAc weakens LCRN interactions without the benefit of charge-charge repulsion or attraction, which plays a critical role in how phosphorylation disrupts or enhances condensates and fibrils formed by other RNAbinding protein LCRs ${ }^{40,41,44}$. Instead, $O$-GlcNAc moieties may disfavour phase separation by altering the hydration properties of the EWS $\mathrm{LCR}_{\mathrm{N}}{ }^{70}$. In addition, the $O$-GlcNAc moiety may itself engage in unique intramolecular interactions with the polypeptide chain that compete with the cohesive intermolecular interactions that are important for phase 
bioRxiv preprint doi: https://doi.org/10.1101/2021.05.11.443654; this version posted May 11, 2021. The copyright holder for this preprint (which was not certified by peer review) is the author/funder, who has granted bioRxiv a license to display the preprint in perpetuity. It is made available under aCC-BY-NC 4.0 International license.

separation and/or aggregation. Evidence from solid-state NMR studies of $O$-GlcNAcylated FG-Nup hydrogels suggest that such novel sugar-protein interactions do exist and are important for altering the rigidity and secondary structural propensities of FG-Nup molecules within the hydrogel ${ }^{22}$.

For several RNA-binding proteins like EWS, phaseseparation propensity has been found to correlate with prionlike sequence characteristics ${ }^{50,71}$. Prions are associated with their propensity to form amyloid fibrillar aggregates that have repetitive cross-beta structure and often exhibit a high resistance to disassembly via chemical or thermal denaturation ${ }^{72}$. Though possessing prion-like sequence characteristics does not necessarily predispose a protein to form such stable structures under physiological conditions, there are a growing number of cases linking the phase separation of PLD-containing proteins with the emergence of fibrillar aggregate states, especially in connection with neurodegenerative disease mutations ${ }^{30,33,38}$. It therefore seems probable that cellular mechanisms such as $O$-GlcNAcylation contribute to preventing the aggregation of PLD-containing proteins, particularly in the context of biomolecular condensates in which the nucleation of such aggregates can be promoted by high protein concentrations.

EWS was recently shown to be co-translationally $O$ GlcNAcylated, and is $O$-GlcNAcylated in several different cell lines $54,55,57,73$. These observations suggest that $O$ GlcNAcylation is a constitutive feature of EWS that imparts a persistent regulatory effect on its cellular functions. Our data provide evidence that $O$-GlcNAcylation could be important for regulating EWS aggregation in the context of cellular condensates, which include poly-ADP-riboseinduced DNA damage puncta, paraspeckles and stress granules ${ }^{64,74,75}$.

EWS $O$-GlcNAcylation was originally discovered in the context of the chimeric fusion protein, EWS-FLI1, in which the C-terminal EWS RBD is swapped for the DNA binding domain of the Friend Leukemia Integration 1 transcription factor (FLI1) due to a chromosomal translocation ${ }^{55}$. EWSFLI1 is the signature oncogenic transcription factor in Ewing sarcoma family tumors, with the EWS $\mathrm{LCR}_{\mathrm{N}}$ acting as a classical activation domain complementing the DNAbinding activity of FLI1. Global inhibition of hexosamine biosynthesis reduces EWS-FLI1 $O$-GlcNAcylation and diminishes the transcriptional output from the EWS-FLI1targeted Id 2 locus in a Ewing Sarcoma cell line ${ }^{55}$. While these results are complicated by the broad off-target effects of hexosamine biosynthesis inhibition, they nevertheless provide compelling initial evidence that $O$-GlcNAcylation affects EWS-FLI1 transcriptional regulation. Recent reports have linked transcription to biomolecular condensates formed by phase separation of transcription factor and coactivator IDRs ${ }^{76,77}$. EWS-FLI1 has been hypothesized to enhance transcription by forming aberrant condensates on repetitive DNA targets of the FLI1 DNA-binding domain ${ }^{78}$, supported by its colocalization to dynamic nuclear 'hubs' containing RNA Pol II ${ }^{49}$. In light of our in vitro results, it would be interesting to test if $O$-GlcNAcylation of EWSFLI1 and other elements of the transcription apparatus, such as the RNA Pol II C-terminal domain (CTD) and TATAbinding protein, affect their partitioning or activity within transcriptional condensates. Indeed, the RNA Pol II CTD and other transcription-associated factors are $O$ -
GlcNAcylated in the pre-initiation complex and are deglycosylated during elongation ${ }^{79,80}$. We speculate that, like phosphorylation ${ }^{81}$, $O$-GlcNAcylation could regulate the exchange of RNA Pol II and other transcription-associated factors between sequential condensates associated with transcription. Further studies are needed to illuminate the rich regulatory potential of $O$-GlcNAcylation for many biomolecular condensates, including those associated with transcription, DNA repair and stress.

\section{EXPERIMENTAL SECTION}

Unless stated otherwise, all chemicals were purchased from BioBasic Canada, Inc. (Markham, ON, Canada).

Plasmids and Cloning. The coding sequence for Homo sapiens EWSR1, residues 1-264 ( $N$-terminal LCR; $\left.\mathrm{LCR}_{\mathrm{N}}\right)$ was synthesized by GenScript (Piscataway, NJ, USA) with codon optimization for expression in Escherichia coli. The $\mathrm{LCR}_{\mathrm{N}}$ coding sequence was inserted in frame with a $\mathrm{N}$ terminal hexahistidine $\left(\mathrm{His}_{6}\right)$-SUMO tag in a Champion $\mathrm{pET}$ SUMO expression vector (Invitrogen, Carlsbad, CA, USA) by Gibson Assembly (New England Biolabs, Ipswich, MA, USA). The coding sequence for EWS 265-656 (the RNA binding domains; RBD) was derived from $H$. sapiens EWSRI cDNA obtained from the NIH Mammalian Gene Collection (MGC), made available through the SickKids SPARC cDNA archive (https://lab.research.sickkids.ca/sparc-drugdiscovery/services/molecular-archives/sparc-cdna-archive/). The RBD fragment was amplified via polymerase chain reaction using Kapa HiFi HotStart ReadyMix (Roche, Basel, Switzerland) and then Gibson assembled in frame with an $\mathrm{N}$ terminal His ${ }_{6}-\mathrm{SUMO}$ tag in the same vector as above. This construct contains a diglycine insertion at the $N$-terminus of the EWS segment (i.e. directly following the SUMO tag and before residue 265 of EWS).

The pET24b H. sapiens '(nucleocytoplasmic variant, $110 \mathrm{kDa})$ E. coli expression plasmid was a kind gift from Suzanne Walker's lab. The K842M mutation was introduced via Site-Directed Mutagenesis using a QuikChange II Kit (Agilent, Santa Clara, CA, USA).

Recombinant Protein Expression. The pET SUMO EWS $\mathrm{LCR}_{\mathrm{N}}$ and EWS RBD plasmids were transformed into E. coli BL21-CodonPlus (DE3) RIPL chemically competent cells (Agilent). EWS RBD methylation was achieved by cotransformation along with a glutathione $S$-transferase-linked protein arginine methyltransferase 1 (PRMT1) E. coli expression vector, as previously described ${ }^{82}$. Successful transformants were selected on lysogeny broth (LB)-agar plates containing $50 \mu \mathrm{g} \mathrm{mL} \mathrm{L}^{-1}$ kanamycin sulfate and $34 \mu \mathrm{g} \mathrm{mL}$ chloramphenicol (also including $100 \mu \mathrm{g} \mathrm{mL} \mathrm{m}^{-1}$ ampicillin in the case of PRMT1 co-expression). Single colonies were used to inoculate $\sim 50 \mathrm{~mL}$ LB overnight cultures containing the same antibiotics. Following overnight incubation at $37^{\circ} \mathrm{C}$ with $250 \mathrm{rpm}$ shaking, these starter cultures were used to inoculate liter-scale cultures which were then incubated under the same conditions until an optical density at $\left(\mathrm{OD}_{600}\right)$ of $\sim 1.0$ was attained. Recombinant protein expression was initiated by the addition of $0.5 \mathrm{mM}$ isopropyl- $\beta-\mathrm{D}$ thiogalactopyranoside (IPTG). The cultures were then incubated for another $\sim 18$ hours at $20^{\circ} \mathrm{C}$ prior to being harvested 
bioRxiv preprint doi: https://doi.org/10.1101/2021.05.11.443654; this version posted May 11, 2021. The copyright holder for this preprint (which was not certified by peer review) is the author/funder, who has granted bioRxiv a license to display the preprint in perpetuity. It is made available under aCC-BY-NC 4.0 International license.

by centrifugation in a JLA9.1000 rotor operating in an Avanti J-26 XP centrifuge (Beckman Coulter, Brea, CA, USA). Cell pellets were suspended in lysis buffer $(25 \mathrm{mM}$ Tris $\mathrm{pH} 8.0,4 \mathrm{M}$ guanidinium chloride, $500 \mathrm{mM} \mathrm{NaCl}, 20 \mathrm{mM}$ imidazole (Millipore-Sigma Canada, Oakville, ON, Canada), $5 \mathrm{mM}$ 2-mercaptoethanol (Millipore-Sigma), $\mathrm{pH}$ 8.0) and stored at $-20^{\circ} \mathrm{C}$ until further use.

Protein Purification. Cells were lysed by sonication using a QSonica Q500 sonicator outfitted with a $6 \mathrm{~mm}$ probe operating at $25 \%$ amplitude with 2 s pulses / $50 \%$ duty for 8 min. total. Lysates were clarified by centrifugation in a JA20 fixed-angle rotor (Beckman Coulter) operated at 15000 rpm for 1 hour at $4^{\circ} \mathrm{C}$. The supernatant was loaded onto a gravity column containing a $\sim 10 \mathrm{~mL}$ bed volume of $\mathrm{Ni} \mathrm{Se}-$ pharose resin (Cytiva, Marlborough, MA, USA) preequilibrated in lysis buffer. After repeated washes with lysis buffer, the bound proteins were eluted with lysis buffer containing $280 \mathrm{mM}$ imidazole. These fractions were pooled and dialyzed against ULP buffer (20mM HEPES, $150 \mathrm{mM} \mathrm{NaCl}$, $2 \mathrm{mM}$ 2-mercaptoethanol) using a $3 \mathrm{kDa}$ molecular weight cut-off (MWCO) regenerated cellulose membrane (Spectrum Chemical MFG Co., New Brunswick, NJ, USA). His ${ }_{6}$-Ulp1 protease (purified in-house) was then added to cleave the SUMO-tag during overnight dialysis at $4^{\circ} \mathrm{C}$. The proteasetreated samples were re-loaded over the nickel column to separate the His $_{6}-\mathrm{SUMO}$ tag and protease from the cleaved protein. The flow-through was concentrated using an Amicon 15mL-volume centrifugal concentrator unit equipped with a $3 \mathrm{kDa}$ MWCO membrane (EMD-Millipore, Burlington, MA, USA) before being injected onto a Superdex 75 16/600 HiLoad column (Cytiva) pre-equilibrated in size exclusion chromatography (SEC) buffer $(25 \mathrm{mM}$ Tris, $2 \mathrm{M}$ guanidinium chloride, $2 \mathrm{mM}$ 2-mercaptoethanol, $\mathrm{pH} 7.5$ ) on an AKTA FPLC chromatography system (Amersham Biosciences Co., Little Chalfont, UK). Proteins were eluted isocratically at a constant flow rate of $0.5 \mathrm{~mL} \mathrm{~min}{ }^{-1}$ with fractions collected every $2 \mathrm{~min}$. Fractions were analyzed by SDS-PAGE with Coomassie staining.

At this stage, the EWS $\mathrm{LCR}_{\mathrm{N}}$ was sufficiently pure for further experiments, whereas the RBD required an additional ion exchange purification step to remove excess impurities. The pooled RBD fractions (with or without PRMT1methylation) were pooled and dialyzed against $25 \mathrm{mM}$ HEPES, $50 \mathrm{mM} \mathrm{NaCl}, \quad 0.5 \mathrm{mM}$ EDTA, 2mM 2mercaptoethanol, $\mathrm{pH} 6.5$ in a $3 \mathrm{kDa}$ MWCO membrane. The dialyzed sample was clarified by centrifugation at 7000rpm in a fixed-angle Thermo F13 rotor in a Sorvall Legend XFR centrifuge (Thermo Scientific, Waltham, MA, USA) at 4degC for 25 minutes before being loaded onto a $5 \mathrm{~mL}$ HiTrap sulfopropyl (SP) HP column (Cytiva) preequilibrated in the same dialysis buffer as above. After washing the resin with several column volumes of dialysis buffer, the bound protein was eluted over a buffer gradient with increasing $\mathrm{NaCl}$ concentration ranging from $50 \mathrm{mM}$ to $2 \mathrm{M}$ (buffer components were otherwise the same as in the dialysis buffer). Fractions were analyzed by SDS-PAGE; most of the RBD eluted at salt concentrations exceeding $0.5 \mathrm{M}$. The purest fractions were pooled and flash frozen for storage at $80^{\circ} \mathrm{C}$

Wild-type and K842M OGT were purified as previously described ${ }^{83}$ with slight modifications. Following the nickel purification, OGT samples were dialyzed against $25 \mathrm{mM}$ Tris, $50 \mathrm{mM} \mathrm{NaCl}, 0.5 \mathrm{mM}$ EDTA, $2 \mathrm{mM}$ dithiothreitol (DTT), pH 7.5 and then concentrated using a centrifugal concentrator equipped with a $50 \mathrm{kDa}$ MWCO membrane. Concentrated samples were injected onto a Superdex 200 16/600 HiLoad column (Cytiva) pre-equilibrated in the same dialysis buffer on an AKTA FPLC chromatography system (Amersham Biosciences Co.). The system was run at $4^{\circ} \mathrm{C}$ with a constant flow rate of $0.5 \mathrm{~mL} \mathrm{~min}^{-1}$ with fractions collected every $2 \mathrm{~min}$. Fractions were analyzed by SDS-PAGE and Coomassie staining to assess purity. The protein was concentrated to working concentrations of $\sim 20-25 \mu \mathrm{M}$ before being flash frozen and stored at $-80^{\circ} \mathrm{C}$ until further use.

In vitro $\boldsymbol{O}$-GIcNAcylation. Unless specified otherwise, $O$ GlcNAcylation reactions contained $10 \mu \mathrm{M}$ of the appropriate protein substrate (e.g., EWS LCR, RBD), $1 \mu \mathrm{M}$ OGT (wildtype or K842M), $1 \mathrm{mM}$ UDP-GlcNAc (Millipore-Sigma), $25 \mathrm{mM}$ Tris, $50 \mathrm{mM} \mathrm{NaCl}, 0.5 \mathrm{mM}$ EDTA, $2 \mathrm{mM}$ dithiothreitol, $\mathrm{pH}$ 7.5. The sample volume was scaled according to the quantity of $O$-GlcNAcylated product desired. Analyticaland preparative-scale reactions were incubated for 14 hours at laboratory temperature $\left(\sim 22^{\circ} \mathrm{C}\right)$ with gentle rocking. Analytical-scale samples were prepared directly for mass spectrometry at this stage (see below), while preparative-scale samples were quenched by the addition of guanidinium chloride (to $2 \mathrm{M}$ final) to facilitate purification by SEC. Concentrated samples were injected onto a Superdex 75 16/600 HiLoad column pre-equilibrated in $25 \mathrm{mM}$ Tris, $2 \mathrm{M}$ guanidinium chloride, $2 \mathrm{mM}$ 2-mercaptoethanol, $\mathrm{pH} 7.5$ on an AKTA FPLC chromatography system. Fractions containing $O$ GlcNAcylated protein were analyzed by SDS-PAGE (a slight migration shift due to $O$-GlcNAcylation was visible as compared to the unmodified protein) and mass spectrometry. The protein was concentrated to $\sim 150 \mu \mathrm{M}$ before being flash frozen and stored at $-80^{\circ} \mathrm{C}$.

Intact Mass Spectrometry (MS). All MS experiments were conducted at the Structural Genomics Consortium (SGC) Toronto facility. Samples were either prepared directly from analytical-scale $O$-GlcNAc reactions or from preparative-scale purified samples that were first exchanged out of guanidinium chloride-containing buffer into $25 \mathrm{mM}$ Tris, $\mathrm{pH}$ 7.5. In either case, formic acid was added to a final concentration of $0.1 \% \mathrm{v} / \mathrm{v}$. $2 \mu \mathrm{L}$ of each sample were injected onto an Agilent UPLC-quadrupolar time of flight (Q-ToF) $6545 \mathrm{MS}$ system equipped with a Dual AJS electrospray ionization source operating in positive ion mode. Samples were desalted online through a $\mathrm{C} 18$ column into a mobile phase containing $95 \% \mathrm{v} / \mathrm{v}$ acetonitrile, $4.5 \% \mathrm{v} / \mathrm{v} \mathrm{H}_{2} \mathrm{O}, 0.5 \% \mathrm{v} / \mathrm{v}$ formic acid. Spectra were recorded over a scan range of 500-3200 m/z at a time interval of 1 scan per second. Raw spectra were processed in Agilent Masshunter software and deconvoluted using the maximum entropy algorithm over a mass range of $10-50 \mathrm{kDa}$ with $1 \mathrm{Da}$ resolution. Raw and deconvoluted spectra were plotted in GraphPad Prism 6.

Fluorescent Protein Labelling. Aliquots of unmodified or $O$-GlcNAcylated EWS $\mathrm{LCR}_{\mathrm{N}}$ were dialyzed in $3.5 \mathrm{kDa}$ MWCO GebaFlex midi cassettes (Gene Bio-Applications Ltd., Yavne, Israel) against $25 \mathrm{mM}$ sodium phosphate, $2 \mathrm{M}$ guanidinium chloride, $\mathrm{pH} 6.5$, to remove the Tris prior to 
bioRxiv preprint doi: https://doi.org/10.1101/2021.05.11.443654; this version posted May 11, 2021. The copyright holder for this preprint (which was not certified by peer review) is the author/funder, who has granted bioRxiv a license to display the preprint in perpetuity. It is made available under aCC-BY-NC 4.0 International license.

labelling. Sulfo-cyanine-3 dye conjugated to $N$ hydroxysuccinimide (sulfo-Cy3 NHS-ester; Lumiprobe Co., Hunt Valley, MD, USA) was dissolved in dimethylformamide (Sigma) to a working concentration of $20 \mathrm{mM}$. An appropriate volume of the dye stock was added into a $20 \mu \mathrm{M}$ sample of dialyzed protein to yield a final dye concentration of $200 \mu \mathrm{M}$. This mixture was allowed to incubate overnight in the dark at $4^{\circ} \mathrm{C}$ to promote selective labelling of the $N$ terminus. The reaction was quenched by the addition of $25 \mathrm{mM}$ Tris, $\mathrm{pH} 7.5$ and filtered through a $0.22 \mu \mathrm{m}$ polyethersulfone membrane (GE Healthcare, Chicago, IL, USA) to remove any aggregates. The filtrate was desalted into $25 \mathrm{mM}$ Tris, $2 \mathrm{M}$ guanidinium chloride, $\mathrm{pH} 7.5$ using a $5 \mathrm{~mL}$ HiTrap desalting column (Cytiva) running at a constant flow rate of $1.5 \mathrm{~mL} \mathrm{~min}^{-1}$ on an AKTA FPLC system. Fractions containing the labelled protein were analyzed by SDS-PAGE to ensure that fluorescent reaction by-products had been removed. Intact mass spectrometric analysis was also used to confirm labelling. Polyacrylamide gels containing the sulfoCy3-modified protein were visualized on a BioRad Chemidoc MP system with Cy3 emission/excitation settings.

Droplet Formation and Microscopy. For all phase separation experiments, EWS $\mathrm{LCR}_{\mathrm{N}}$ (with or without $O$ GlcNAcylation or sulfo-Cy3-labelling) was exchanged into $25 \mathrm{mM}$ Tris, $\mathrm{pH} 7.5$, by successively concentrating and diluting the protein out of the original guanidinium chloridecontaining storage buffer. During this process, the temperature of the centrifuge chamber was set to $\geq 37^{\circ} \mathrm{C}$ to limit precipitation which occurred more readily at lower temperature. Droplet formation was induced by combining protein samples 1:1 with buffers containing twice the appropriate $\mathrm{NaCl}$ concentration at room temperature. For DIC microscopy, droplet samples were pipetted directly into the wells of 96well polystyrene glass-bottom plates (Eppendorf, Hamburg, Germany). Images were acquired on a Zeiss Axio Observer 7 microscope with a 40x air objective lens. For fluorescence microscopy, $5 \mu \mathrm{L}$ samples were pipetted into $35 \mathrm{~mm}$-diameter uncoated no. 1.5 glass-bottom dishes (MatTek, Ashland, MA, USA) which were subsequently sealed with a glass coverslip to limit evaporation. To enable non-wetting conditions for fusion experiments, the dishes were pre-treated with Sigmacote (Millipore-Sigma) according to the manufacturer's instructions. Fluorescence imaging was performed on a Leica TCS SP8 Lightning / DMi8 system equipped with a Hamamatsu C9100-13 EM-CCD camera. All images were acquired with a $63 \mathrm{x}$ oil-immersion objective lens at $1024 \times 1024$ pixel resolution. Sulfo-Cy3 fluorescence was detected with a Leica hybrid detector (HyD) following excitation with a $561 \mathrm{~nm}(40 \mathrm{~mW})$ laser. Image files were analyzed and processed using Fiji (https://imagej.net/Fiji).

Fluorescence Recovery After Photobleaching (FRAP). FRAP data were collected using the LAS X FRAP module on the same Leica system described above. Circular, $2.5 \mu \mathrm{m}$ diameter regions of interest (ROI) were positioned in the centres of droplets for bleaching, which was performed in a single pulse at $30 \%$ laser power on zoom-in mode. After photobleaching, images were acquired at a frequency of $0.77 \mathrm{~s}^{-1}$. Fluorescence intensity measurements from inside the bleached ROI were normalized to measurements from a separate ROI in an adjacent unbleached droplet to correct for passive photobleaching and focus drift. The values were then normalized to the average of 5 pre-bleach scans to yield relative intensity values. The recovery timescale was obtained by fitting a single exponential curve to the processed data: $I(t)=a-b e^{-t / \tau}$, where $I(\mathrm{t})$ is relative intensity at each time, $\mathrm{t}$, and $\mathrm{a}, \mathrm{b}$ and $\tau$ are fit parameters. Half-times were calculated as $t_{1 / 2}=\tau \ln 2$.

Turbidity Assays. Samples were prepared in 96-well clear polystyrene plates prior to being transferred into a 384well black polystyrene glass-bottom plate (Corning, Corning, NY, USA) for measurement on a SpectriMax i3x plate reader (Molecular Devices, San Jose, CA, USA). The assay buffers typically contained $25 \mathrm{mM}$ Tris, $0.5 \mathrm{mM}$ EDTA, $2 \mathrm{mM}$ DTT, $\mathrm{pH} 7.5$ with a variable $\mathrm{NaCl}$ concentrations (to promote or prevent droplet formation) depending on the experimental setup. All sample had a final volume of $15 \mu \mathrm{L}$ per well. Absorbance measurements were collected at 25 with $500 \mathrm{~nm}$-wavelength light at a read-height of $12 \mathrm{~mm}$. Data were processed and plotted in GraphPad Prism 6.

Temperature Ramp Experiments. EWS $\mathrm{LCR}_{\mathrm{N}}$ (with or without $O$-GlcNAcylation) was dialyzed against $20 \mathrm{mM} 3$ ( $N$-morpholino)propanesulfonic acid (MOPS), pH 7.5 in a $3 \mathrm{kDa}$ MWCO GebaFlex midi cassettes (Gene BioApplications Ltd.) overnight at room temperature. $200 \mu \mathrm{L}$ samples were prepared at $30 \mu \mathrm{M}$ final protein concentration in $20 \mathrm{mM}$ MOPS, $150 \mathrm{mM} \mathrm{NaCl}, \mathrm{pH} 7.5$, with different ratios of unmodified:modified EWS $\mathrm{LCR}_{\mathrm{N}}$ present. Samples were pipetted into $250 \mu \mathrm{L} 1 \mathrm{~mm}$-thick quartz cuvette for turbidity measurements in a JASCO J-1500 circular dichroism spectrophotometer.

Calculating percentages of predicted phase separating proteins. The predictions of phase separation propensities for human proteins were available from Vernon et al. ${ }^{67}$. The predictions from three different metrics (catGRANULE ${ }^{65}$, PScore ${ }^{9}$ and PLAAC ${ }^{66}$ ) were considered, with methodspecific cut-offs used to define propensity to phase separate in a binary manner. A value larger than zero for catGRANULE score was used to define propensity to phase separate. The same cut-off $(>0)$ was used to identify proteins that contain probable prion-like domains by PLAAC. The cut-off of larger or equal than four was used for PScore, as previously established by the authors of the original work. The prediction scores of the three metrics were in addition expressed as a percentage of the human proteome predicted to phase separate in order to unify different scoring schemes across the predictors, with $4 \%$ of the human proteome used as a cut-off. The list of sequences of all proteins currently in the PhosphositePlus database was retrieved from the website (https://www.phosphosite.org/Phosphosite_seq.fasta). The set of $O$-GlcNAc modified protein sequences was retrieved from the same database (O-GlcNAc_site_dataset). Both datasets were filtered to include human proteins only. The fractions of the proteins predicted to phase separate in each of the categories: i) proteome; ii) PhosphositePlus; and iii) $O$ GlcNAc, were computed by dividing the number of proteins above the cut-off of each of the metrics (PScore, PLAAC, catGRANULE) by the total number of proteins in each category. A Fisher's exact test was used to assess the signifi- 
bioRxiv preprint doi: https://doi.org/10.1101/2021.05.11.443654; this version posted May 11, 2021. The copyright holder for this preprint (which was not certified by peer review) is the author/funder, who has granted bioRxiv a license to display the preprint in perpetuity. It is made available under aCC-BY-NC 4.0 International license.

cance of the difference between the fraction of proteins above the threshold in the human proteome and each of the categories (the $p$-values of the test given in Table $\mathrm{S} 1$; and significance indicated with i) '*' $P \leq 0.01$; ii) ' $* * ' P \leq 0.001$; iii) '***' $P \leq 0.0001)$.

Defining proteins with long IDRs. SPOT-Disorder ${ }^{84}$ was run on the reference human proteome from Uniprot (UP000005640, downloaded on Aug 8, 2019), to obtain a residue-level prediction of intrinsic disorder for all human proteins (canonical sequences only). Short sequences of seven or less residues of predicted 'order' mapped in between long predicted disorder regions were concatenated into the predicted disordered regions. A cut-off of 100 consecutive residues of predicted disorder was used to define 'long IDRs'.

Cell culture and siRNA transfection. Please refer to Table S2 for a detailed list of antibodies used in this study.

HeLa cells were cultured in Dulbecco's Modified Eagle Medium (DMEM) with 10\% fetal bovine serum and $1 \%$ penicillin-streptomycin. To downregulate expression of $O G T$, cells were reverse-transfected with $20 \mathrm{nM} O \mathrm{ON}-$ TARGETplus Human $O G T$ siRNA (Horizon, cat. no. J019111-06) for 48 hours using INTERFERin siRNA Transfection Reagent (Polyplus, Illkirch-Graffenstaden, France). Knockdown efficiency was verified by immunoblotting with an anti-OGT antibody (Abcam, Cambridge, UK), while global $O$-GlcNAc levels were assessed by immunoblotting with an anti-O-GlcNAc (RL2) antibody (Abcam).

$O$-GlcNAc stoichiometries on EWS and TAF15 in HeLa cell lysates were measured by Western blotting with the appropriate antibodies (Abcam) after the lysates were processed with the ClickIT $O$-GlcNAc Enzymatic Labelling and ClickIT detection assay kits (Invitrogen). Volumes of lysate containing $\sim 200 \mu \mathrm{g}$ of protein dissolved in FRA buffer (see below) were used for these assays. The manufacturer's instructions were followed, with the exception that the alkynebiotin detection reagent from the latter kit was replaced with methoxy-PEG-alkyne (average MW $\sim 5 \mathrm{kDa}$; Biochempeg, Watertown, MA, USA), which was present at a final concentration of $5 \mathrm{mM}$ during the Click chemistry step. After the final protein precipitation step, the pellets were resuspended in $50 \mu \mathrm{L}$ of $4 \mathrm{x}$ Bolt LDS sample buffer (Invitrogen) after vigorous vortexing and heating at $70^{\circ} \mathrm{C}$. Samples were diluted four-fold with water before being loaded onto a 4-20\% tris-glycine polyacrylamide gel (BioRad, Hercules, CA, USA), approximately $\sim 10 \mu \mathrm{g}$ of protein (i.e., $4 \mu \mathrm{L}$ of undiluted dissolved pellet diluted to $16 \mu \mathrm{L}$ with water) per lane. SDS-PAGE and Western blotting were performed according to standard protocols.

Filter retardation assay (FRA). siRNA-transfected cells were harvested and lysed in FRA lysis buffer (20 mM Tris$\mathrm{HCl} \mathrm{pH}$ 7.5, $150 \mathrm{mM} \mathrm{NaCl}, 1 \mathrm{mM}$ EDTA, 1 mM EGTA, 1\% Triton X-100, 1x protease inhibitor cocktail) and protein concentration was quantified using a Pierce 660 assay (Thermo Scientific, cat. no. 22660). 10 $\mu$ g of lysate was loaded onto a methanol-activated $0.2 \mu \mathrm{m}$ cellulose-acetate membrane in a BioRad slot-blot apparatus. The wells of the apparatus were washed prior to and after sample loading using RIPA buffer (50mM Tris- $\mathrm{HCl} \mathrm{pH} 7.5,150 \mathrm{mM} \mathrm{NaCl}, 1 \% \mathrm{v} / \mathrm{v}$
Triton X-100, $0.5 \% \mathrm{w} / \mathrm{v}$ sodium deoxycholate, $0.1 \% \mathrm{w} / \mathrm{v}$ SDS, $5 \mathrm{mM}$ EDTA, 1x protease inhibitor cocktail). Following sample loading and washes, the cellulose-acetate membrane was fixed in methanol for 5 minutes, washed in trisbuffered saline with $0.1 \% \mathrm{v} / \mathrm{v}$ Tween-20 (TBST) for 5 minutes, and subsequently processed for immunoblotting. In brief, the membrane was blocked in $5 \% \mathrm{w} / \mathrm{v}$ skim milk powder / TBST, incubated in primary antibody (anti-EWS and anti-TAF15; overnight at $4^{\circ} \mathrm{C}$ ), incubated in horseradish peroxidase (HRP)-linked secondary antibody (anti-rabbit IgG; $1 \mathrm{hr}$ at RT), and developed on a ChemiDoc Gel Imaging System using Luminata Crescendo Western HRP Substrate (Sigma, WBLUR0500). Signal intensity was quantified using the Gel Analyzer plugin in ImageJ. Three technical replicates were performed for each experiment. Western blots were performed in parallel to ensure equal loading and levels of expression of the proteins of interest. 
bioRxiv preprint doi: https://doi.org/10.1101/2021.05.11.443654; this version posted May 11, 2021. The copyright holder for this preprint (which was not certified by peer review) is the author/funder, who has granted bioRxiv a license to display the preprint in perpetuity. It is made available under aCC-BY-NC 4.0 International license.

\section{ASSOCIATED CONTENT}

\section{Supporting Information}

Supplementary mass spectrometry data, including raw spectra of

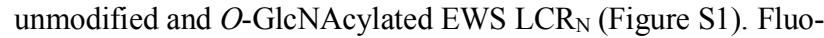
rescence micrographs to accompany FRAP data from $\mathrm{LCR}_{\mathrm{N}}+\mathrm{RBD}$ droplets in Fig. 4 (Figure S2). Western blots showing (i) depletion of OGT following siOGT treatment of HeLa cells, (ii) lack of $O$-GlcNAcylation on TAF15 in HeLa cells, (iii) negligible changes in EWS and TAF15 expression levels following siOGT treatment (Figure S3). Supplementary bioinformatics data on differential prediction of phase separation propensity for proteins in the human proteome, including those filtered for containing long ( $>100$ residue) IDRs (Figure S4). Tabulated data corresponding to the bioinformatic analyses presented in Figs. 6 and S4 (Table S1). A listed of antibodies used in this study (Table S2).

The Supporting Information is available free of charge on the ACS Publications website.

\section{AUTHOR INFORMATION}

\section{Corresponding Author}

* forman@sickkids.ca

\section{Notes}

The authors declare no competing financial interest.

\section{Funding Sources}

M.N. is funded by an Alexander Graham Bell Canada Graduate Scholarship - Doctoral from the Natural Sciences and Engineering Research Council (NSERC) and M.T. by a Vanier Graduate Scholarship. This work was supported by funding to J.D.F.-K. from the Canadian Institutes for Health Research (CIHR) FDN148375 and the Canadian Cancer Society, to both J.D.F.-K. and H.O.L. from the Canada Research Chair program, and to H.O.L. from NSERC and University of Toronto's Connaught Fund and Medicine by Design, which receives funding from the Canada First Research Excellence Fund. Additional support was from Children's Cancer Foundation, Inc. as a Force 3 Fellowship (J. A.T.), and the NIH R01CA233619-01A1 (J.A.T.), LCCC CCSG Grant P30 CA051008-16 (Lou Weiner, PI, J.A.T.).

\section{ACKNOWLEDGMENT}

We would like to thank the SickKids Imaging Facility for their assistance with the microscopy experiments.

\section{REFERENCES}

1. Banani, S. F.; Lee, H. O.; Hyman, A. A.; Rosen, M. K., Biomolecular condensates: organizers of cellular biochemistry. Nat Rev Mol Cell Biol 2017, 18 (5), 285-298.

2. Shin, Y.; Brangwynne, C. P., Liquid phase condensation in cell physiology and disease. Science 2017, 357 (6357).

3. Boeynaems, S.; Alberti, S.; Fawzi, N. L.; Mittag, T.; Polymenidou, M.; Rousseau, F.; Schymkowitz, J.; Shorter, J.; Wolozin, B.; Van Den Bosch, L.; Tompa, P.; Fuxreiter, M., Protein Phase Separation: A New Phase in Cell Biology. Trends Cell Biol 2018, 28 (6), 420-435.

4. Lin, Y. H.; Forman-Kay, J. D.; Chan, H. S., Theories for Sequence-Dependent Phase Behaviors of Biomolecular Condensates. Biochemistry 2018, 57 (17), 2499-2508.

5. Brangwynne, C. P.; Tompa, P.; Pappu, R. V., Polymer physics of intracellular phase transitions. Nature Physics 2015, 11 (11), 899-904.
6. Hofweber, M.; Dormann, D., Friend or foe-Posttranslational modifications as regulators of phase separation and RNP granule dynamics. J Biol Chem 2019, 294 (18), 7137-7150.

7. Leung, A. K. L., Poly(ADP-ribose): A Dynamic Trigger for Biomolecular Condensate Formation. Trends Cell Biol 2020, 30 (5), 370-383

8. Owen, I.; Shewmaker, F., The Role of Post-Translational Modifications in the Phase Transitions of Intrinsically Disordered Proteins. Int J Mol Sci 2019, 20 (21).

9. Vernon, R. M.; Chong, P. A.; Tsang, B.; Kim, T. H.; Bah, A.; Farber, P.; Lin, H.; Forman-Kay, J. D., Pi-Pi contacts are an overlooked protein feature relevant to phase separation. Elife 2018, 7 .

10. Kim, T. H.; Tsang, B.; Vernon, R. M.; Sonenberg, N.; Kay, L. E.; Forman-Kay, J. D., Phospho-dependent phase separation of FMRP and CAPRIN1 recapitulates regulation of translation and deadenylation. Science 2019, 365, 825-829.

11. Zachara, N.; Akimoto, Y.; Hart, G. W., The O-GlcNAc Modification. In Essentials of Glycobiology, rd; Varki, A.; Cummings, R. D.; Esko, J. D.; Stanley, P.; Hart, G. W.; Aebi, M.; Darvill, A. G.; Kinoshita, T.; Packer, N. H.; Prestegard, J. H.; Schnaar, R. L.; Seeberger, P. H., Eds. Cold Spring Harbor (NY), 2015; pp 239-251.

12. Levine, Z. G.; Potter, S. C.; Joiner, C. M.; Fei, G. Q.; Nabet, B.; Sonnett, M.; Zachara, N. E.; Gray, N. S.; Paulo, J. A.; Walker, S., Mammalian cell proliferation requires noncatalytic functions of O-GlcNAc transferase. Proc Natl Acad Sci U S A 2021, $118(4)$.

13. Hart, G. W., Nutrient regulation of signaling and transcription. J Biol Chem 2019, 294 (7), 2211-2231.

14. Liu, C.; Li, J., O-GlcNAc: A Sweetheart of the Cell Cycle and DNA Damage Response. Front Endocrinol (Lausanne) 2018, 9, 415 .

15. Yang, X.; Qian, K., Protein O-GlcNAcylation: emerging mechanisms and functions. Nat Rev Mol Cell Biol 2017, 18 (7), $452-465$.

16. Ong, Q.; Han, W.; Yang, X., O-GlcNAc as an Integrator of Signaling Pathways. Front Endocrinol (Lausanne) 2018, 9, 599.

17. Akan, I.; Olivier-Van Stichelen, S.; Bond, M. R.; Hanover, J. A., Nutrient-driven O-GlcNAc in proteostasis and neurodegeneration. $J$ Neurochem 2018, 144 (1), 7-34.

18. Hardiville, S.; Hart, G. W., Nutrient regulation of gene expression by O-GlcNAcylation of chromatin. Curr Opin Chem Biol 2016, 33, 88-94.

19. Ohn, T.; Kedersha, N.; Hickman, T.; Tisdale, S.; Anderson, P., A functional RNAi screen links O-GlcNAc modification of ribosomal proteins to stress granule and processing body assembly. Nat Cell Biol 2008, 10 (10), 1224-31.

20. Chen, Q.; Yu, X., OGT restrains the expansion of DNA damage signaling. Nucleic Acids Res 2016, 44 (19), 9266-9278.

21. Gambetta, M. C.; Muller, J., O-GlcNAcylation prevents aggregation of the Polycomb group repressor polyhomeotic. Dev Cell 2014, 31 (5), 629-39.

22. Labokha, A. A.; Gradmann, S.; Frey, S.; Hulsmann, B. B.; Urlaub, H.; Baldus, M.; Gorlich, D., Systematic analysis of barrier-forming FG hydrogels from Xenopus nuclear pore complexes. EMBO J 2013, 32 (2), 204-18.

23. Marotta, N. P.; Lin, Y. H.; Lewis, Y. E.; Ambroso, M. R.; Zaro, B. W.; Roth, M. T.; Arnold, D. B.; Langen, R.; Pratt, M. R., O-GlcNAc modification blocks the aggregation and toxicity of the protein alpha-synuclein associated with Parkinson's disease. Nat Chem 2015, 7 (11), 913-20.

24. Lewis, Y. E.; Galesic, A.; Levine, P. M.; De Leon, C. A.; Lamiri, N.; Brennan, C. K.; Pratt, M. R., O-GlcNAcylation of alpha-Synuclein at Serine 87 Reduces Aggregation without Affecting Membrane Binding. ACS Chem Biol 2017, 12 (4), 10201027.

25. Yuzwa, S. A.; Shan, X.; Macauley, M. S.; Clark, T.; Skorobogatko, Y.; Vosseller, K.; Vocadlo, D. J., Increasing OGlcNAc slows neurodegeneration and stabilizes tau against aggregation. Nat Chem Biol 2012, 8 (4), 393-9. 
bioRxiv preprint doi: https://doi.org/10.1101/2021.05.11.443654; this version posted May 11, 2021. The copyright holder for this preprint (which was not certified by peer review) is the author/funder, who has granted bioRxiv a license to display the preprint in perpetuity. It is made available under aCC-BY-NC 4.0 International license.

26. Ray, S.; Singh, N.; Kumar, R.; Patel, K.; Pandey, S.; Datta, D.; Mahato, J.; Panigrahi, R.; Navalkar, A.; Mehra, S.; Gadhe, L.; Chatterjee, D.; Sawner, A. S.; Maiti, S.; Bhatia, S.; Gerez, J. A.; Chowdhury, A.; Kumar, A.; Padinhateeri, R.; Riek, R.; Krishnamoorthy, G.; Maji, S. K., alpha-Synuclein aggregation nucleates through liquid-liquid phase separation. Nat Chem 2020, $12(8), 705-716$.

27. Kanaan, N. M.; Hamel, C.; Grabinski, T.; Combs, B., Liquid-liquid phase separation induces pathogenic tau conformations in vitro. Nat Commun 2020, 11 (1), 2809.

28. Wegmann, S.; Eftekharzadeh, B.; Tepper, K.; Zoltowska, K. M.; Bennett, R. E.; Dujardin, S.; Laskowski, P. R.; MacKenzie, D.; Kamath, T.; Commins, C.; Vanderburg, C.; Roe, A. D.; Fan, Z.; Molliex, A. M.; Hernandez-Vega, A.; Muller, D.; Hyman, A. A.; Mandelkow, E.; Taylor, J. P.; Hyman, B. T., Tau protein liquid-liquid phase separation can initiate tau aggregation. EMBO J 2018, 37 (7).

29. Boyko, S.; Surewicz, K.; Surewicz, W. K., Regulatory mechanisms of tau protein fibrillation under the conditions of liquid-liquid phase separation. Proc Natl Acad Sci U S A 2020, 117 (50), 31882-31890.

30. Patel, A.; Lee, H. O.; Jawerth, L.; Maharana, S.; Jahnel, M.; Hein, M. Y.; Stoynov, S.; Mahamid, J.; Saha, S.; Franzmann, T. M.; Pozniakovski, A.; Poser, I.; Maghelli, N.; Royer, L. A.; Weigert, M.; Myers, E. W.; Grill, S.; Drechsel, D.; Hyman, A. A.; Alberti, S., A Liquid-to-Solid Phase Transition of the ALS Protein FUS Accelerated by Disease Mutation. Cell 2015, 162 (5), 1066-77.

31. Molliex, A.; Temirov, J.; Lee, J.; Coughlin, M.; Kanagaraj, A. P.; Kim, H. J.; Mittag, T.; Taylor, J. P., Phase separation by low complexity domains promotes stress granule assembly and drives pathological fibrillization. Cell 2015, 163 (1), 123-33.

32. Lin, Y.; Protter, D. S.; Rosen, M. K.; Parker, R., Formation and Maturation of Phase-Separated Liquid Droplets by RNA-Binding Proteins. Mol Cell 2015, 60 (2), 208-19.

33. Kato, M.; Han, T. W.; Xie, S.; Shi, K.; Du, X.; Wu, L. C.; Mirzaei, H.; Goldsmith, E. J.; Longgood, J.; Pei, J.; Grishin, N. V.; Frantz, D. E.; Schneider, J. W.; Chen, S.; Li, L.; Sawaya, M. R.; Eisenberg, D.; Tycko, R.; McKnight, S. L., Cell-free formation of RNA granules: low complexity sequence domains form dynamic fibers within hydrogels. Cell 2012, 149 (4), 753-67.

34. Hennig, S.; Kong, G.; Mannen, T.; Sadowska, A.; Kobelke, S.; Blythe, A.; Knott, G. J.; Iyer, K. S.; Ho, D.; Newcombe, E. A.; Hosoki, K.; Goshima, N.; Kawaguchi, T.; Hatters, D.; Trinkle-Mulcahy, L.; Hirose, T.; Bond, C. S.; Fox, A. H., Prion-like domains in RNA binding proteins are essential for building subnuclear paraspeckles. J Cell Biol 2015, 210 (4), 529-39.

35. Khan, T.; Kandola, T. S.; Wu, J.; Venkatesan, S.; Ketter, E.; Lange, J. J.; Rodriguez Gama, A.; Box, A.; Unruh, J. R.; Cook, M.; Halfmann, R., Quantifying Nucleation In Vivo Reveals the Physical Basis of Prion-like Phase Behavior. Mol Cell 2018, 71 (1), 155-168 e7.

36. Guo, L.; Kim, H. J.; Wang, H.; Monaghan, J.; Freyermuth, F.; Sung, J. C.; O'Donovan, K.; Fare, C. M.; Diaz, Z.; Singh, N.; Zhang, Z. C.; Coughlin, M.; Sweeny, E. A.; DeSantis, M. E.; Jackrel, M. E.; Rodell, C. B.; Burdick, J. A.; King, O. D.; Gitler, A. D.; Lagier-Tourenne, C.; Pandey, U. B.; Chook, Y. M.; Taylor, J. P.; Shorter, J., Nuclear-Import Receptors Reverse Aberrant Phase Transitions of RNA-Binding Proteins with Prion-like Domains. Cell 2018, 173 (3), 677-692 e20.

37. Franzmann, T. M.; Alberti, S., Prion-like low-complexity sequences: Key regulators of protein solubility and phase behavior. J Biol Chem 2019, 294 (18), 7128-7136.

38. Murray, D. T.; Zhou, X.; Kato, M.; Xiang, S.; Tycko, R.; McKnight, S. L., Structural characterization of the D290V mutation site in hnRNPA2 low-complexity-domain polymers. Proc Natl Acad Sci U S A 2018, 115 (42), E9782-E9791.

39. Conicella, A. E.; Dignon, G. L.; Zerze, G. H.; Schmidt, H. B.; D'Ordine, A. M.; Kim, Y. C.; Rohatgi, R.; Ayala, Y. M.; Mittal, J.; Fawzi, N. L., TDP-43 alpha-helical structure tunes liquid- liquid phase separation and function. Proc Natl Acad Sci U S A 2020, 117 (11), 5883-5894.

40. Murray, D. T.; Kato, M.; Lin, Y.; Thurber, K. R.; Hung, I.; McKnight, S. L.; Tycko, R., Structure of FUS Protein Fibrils and Its Relevance to Self-Assembly and Phase Separation of Low-Complexity Domains. Cell 2017, 171 (3), 615-627 e16.

41. Kwon, I.; Kato, M.; Xiang, S.; Wu, L.; Theodoropoulos, P.; Mirzaei, H.; Han, T.; Xie, S.; Corden, J. L.; McKnight, S. L., Phosphorylation-regulated binding of RNA polymerase II to fibrous polymers of low-complexity domains. Cell 2013, 155 (5), 1049-1060.

42. Wang, A.; Conicella, A. E.; Schmidt, H. B.; Martin, E. W.; Rhoads, S. N.; Reeb, A. N.; Nourse, A.; Ramirez Montero, D.; Ryan, V. H.; Rohatgi, R.; Shewmaker, F.; Naik, M. T.; Mittag, T.; Ayala, Y. M.; Fawzi, N. L., A single N-terminal phosphomimic disrupts TDP-43 polymerization, phase separation, and RNA splicing. EMBO J 2018, 37 (5).

43. Afroz, T.; Hock, E. M.; Ernst, P.; Foglieni, C.; Jambeau, M.; Gilhespy, L. A. B.; Laferriere, F.; Maniecka, Z.; Pluckthun, A.; Mittl, P.; Paganetti, P.; Allain, F. H. T.; Polymenidou, M., Functional and dynamic polymerization of the ALS-linked protein TDP-43 antagonizes its pathologic aggregation. Nat Commun 2017, 8 (1), 45.

44. Monahan, Z.; Ryan, V. H.; Janke, A. M.; Burke, K. A.; Rhoads, S. N.; Zerze, G. H.; O'Meally, R.; Dignon, G. L.; Conicella, A. E.; Zheng, W.; Best, R. B.; Cole, R. N.; Mittal, J.; Shewmaker, F.; Fawzi, N. L., Phosphorylation of the FUS lowcomplexity domain disrupts phase separation, aggregation, and toxicity. EMBO J 2017, 36 (20), 2951-2967.

45. Franzmann, T. M.; Jahnel, M.; Pozniakovsky, A.; Mahamid, J.; Holehouse, A. S.; Nuske, E.; Richter, D.; Baumeister, W.; Grill, S. W.; Pappu, R. V.; Hyman, A. A.; Alberti, S., Phase separation of a yeast prion protein promotes cellular fitness. Science 2018, 359 (6371).

46. Feric, M.; Vaidya, N.; Harmon, T. S.; Mitrea, D. M.; Zhu, L.; Richardson, T. M.; Kriwacki, R. W.; Pappu, R. V.; Brangwynne, C. P., Coexisting Liquid Phases Underlie Nucleolar Subcompartments. Cell 2016, 165 (7), 1686-1697.

47. Putnam, A.; Cassani, M.; Smith, J.; Seydoux, G., A gel phase promotes condensation of liquid $\mathrm{P}$ granules in Caenorhabditis elegans embryos. Nat Struct Mol Biol 2019, 26 (3), 220-226.

48. Kroschwald, S.; Munder, M. C.; Maharana, S.; Franzmann, T. M.; Richter, D.; Ruer, M.; Hyman, A. A.; Alberti, S., Different Material States of Pub1 Condensates Define Distinct Modes of Stress Adaptation and Recovery. Cell Rep 2018, 23 (11), 3327-3339.

49. Chong, S.; Dugast-Darzacq, C.; Liu, Z.; Dong, P.; Dailey, G. M.; Cattoglio, C.; Heckert, A.; Banala, S.; Lavis, L.; Darzacq, X.; Tjian, R., Imaging dynamic and selective lowcomplexity domain interactions that control gene transcription. Science 2018, 361 (6400).

50. Wang, J.; Choi, J. M.; Holehouse, A. S.; Lee, H. O.; Zhang, X.; Jahnel, M.; Maharana, S.; Lemaitre, R.; Pozniakovsky, A.; Drechsel, D.; Poser, I.; Pappu, R. V.; Alberti, S.; Hyman, A. A., A Molecular Grammar Governing the Driving Forces for Phase Separation of Prion-like RNA Binding Proteins. Cell 2018, 174 (3), 688-699 e16.

51. Maharana, S. W., J.; Papadopoulos, D. K.; Richterm D.; Pozniakovsky, A.; Poser, I.; Bickle, M.; Rizk, S.; Guillen-Boixet, J.; Franzmann, T.; Jahnel, M.; Marrone, L.; Chang, Y.-T.; Sterneckert, J.; Tomancak, T.; Hyman, A. A.; Alberti, S., RNA buffers the phase separation behavior of prion-like RNA binding proteins. Science 2018, 360, 918-921.

52. Hofweber, M.; Hutten, S.; Bourgeois, B.; Spreitzer, E.; Niedner-Boblenz, A.; Schifferer, M.; Ruepp, M. D.; Simons, M.; Niessing, D.; Madl, T.; Dormann, D., Phase Separation of FUS Is Suppressed by Its Nuclear Import Receptor and Arginine Methylation. Cell 2018, 173 (3), 706-719 e13.

53. Boulay, G.; Sandoval, G. J.; Riggi, N.; Iyer, S.; Buisson, R.; Naigles, B.; Awad, M. E.; Rengarajan, S.; Volorio, A.; McBride, M. J.; Broye, L. C.; Zou, L.; Stamenkovic, I.; 
bioRxiv preprint doi: https://doi.org/10.1101/2021.05.11.443654; this version posted May 11, 2021. The copyright holder for this preprint (which was not certified by peer review) is the author/funder, who has granted bioRxiv a license to display the preprint in perpetuity. It is made available under aCC-BY-NC 4.0 International license.

Kadoch, C.; Rivera, M. N., Cancer-Specific Retargeting of BAF Complexes by a Prion-like Domain. Cell 2017, 171 (1), 163-178 e19.

54. Kamemura, K., O-GlcNAc glycosylation stoichiometry of the FET protein family: only EWS is glycosylated with a high stoichiometry. Biosci Biotechnol Biochem 2017, 81 (3), 541-546.

55. Bachmaier, R.; Aryee, D. N.; Jug, G.; Kauer, M.; Kreppel, M.; Lee, K. A.; Kovar, H., O-GlcNAcylation is involved in the transcriptional activity of EWS-FLI1 in Ewing's sarcoma. Oncogene 2009, 28 (9), 1280-4.

56. Hanover, J. A., Yu, S., Lubas, W.B., Shin, S.-H., Ragano-Caracciola, M., Kochran, J., Love, D.C., Mitochondrial and nucleocytoplasmic isoforms of O-linked GlcNAc transferase encoded by a single mammalian gene. Arch Biochem Biophys 2003, 409, 287-297.

57. Kamemura, K.; Abe, H., The glycosylation stoichiometry of EWS species in neuronal cells. Biosci Biotechnol Biochem 2017, 81 (1), 165-167.

58. Burke, K. A.; Janke, A. M.; Rhine, C. L.; Fawzi, N. L., Residue-by-Residue View of In Vitro FUS Granules that Bind the C-Terminal Domain of RNA Polymerase II. Mol Cell 2015, 60 (2), 231-41.

59. Brangwynne, C. P.; Mitchison, T. J.; Hyman, A. A., Active liquid-like behavior of nucleoli determines their size and shape in Xenopus laevis oocytes. Proc Natl Acad Sci U S A 2011, $108(11), 4334-9$.

60. Elbaum-Garfinkle, S.; Kim, Y.; Szczepaniak, K.; Chen, C. C.; Eckmann, C. R.; Myong, S.; Brangwynne, C. P., The disordered $\mathrm{P}$ granule protein LAF-1 drives phase separation into droplets with tunable viscosity and dynamics. Proc Natl Acad Sci U $S$ A 2015, 112 (23), 7189-94.

61. Boeynaems, S.; Holehouse, A. S.; Weinhardt, V.; Kovacs, D.; Van Lindt, J.; Larabell, C.; Van Den Bosch, L.; Das, R.; Tompa, P. S.; Pappu, R. V.; Gitler, A. D., Spontaneous driving forces give rise to protein-RNA condensates with coexisting phases and complex material properties. Proc Natl Acad Sci U S A 2019, 116 (16), 7889-7898.

62. Taylor, N. O.; Wei, M. T.; Stone, H. A.; Brangwynne, C. P., Quantifying Dynamics in Phase-Separated Condensates Using Fluorescence Recovery after Photobleaching. Biophys $J$ 2019, 117 (7), 1285-1300

63. Qamar, S.; Wang, G.; Randle, S. J.; Ruggeri, F. S.; Varela, J. A.; Lin, J. Q.; Phillips, E. C.; Miyashita, A.; Williams, D.; Strohl, F.; Meadows, W.; Ferry, R.; Dardov, V. J.; Tartaglia, G. G.; Farrer, L. A.; Kaminski Schierle, G. S.; Kaminski, C. F.; Holt, C. E.; Fraser, P. E.; Schmitt-Ulms, G.; Klenerman, D.; Knowles, T.; Vendruscolo, M.; St George-Hyslop, P., FUS Phase Separation Is Modulated by a Molecular Chaperone and Methylation of Arginine Cation-pi Interactions. Cell 2018, 173 (3), 720-734 e15.

64. Altmeyer, M.; Neelsen, K. J.; Teloni, F.; Pozdnyakova, I.; Pellegrino, S.; Grofte, M.; Rask, M. D.; Streicher, W.; Jungmichel, S.; Nielsen, M. L.; Lukas, J., Liquid demixing of intrinsically disordered proteins is seeded by poly(ADP-ribose). Nat Commun 2015, 6, 8088 .

65. Bolognesi, B.; Lorenzo Gotor, N.; Dhar, R.; Cirillo, D.; Baldrighi, M.; Tartaglia, G. G.; Lehner, B., A ConcentrationDependent Liquid Phase Separation Can Cause Toxicity upon Increased Protein Expression. Cell Rep 2016, 16 (1), 222-231.

66. Lancaster, A. K.; Nutter-Upham, A.; Lindquist, S.; King, O. D., PLAAC: a web and command-line application to identify proteins with prion-like amino acid composition. Bioinformatics 2014, 30 (17), 2501-2.

67. Vernon, R. M.; Forman-Kay, J. D., First-generation predictors of biological protein phase separation. Curr Opin Struct Biol 2019, 58, 88-96.

68. Srikanth, B.; Vaidya, M. M.; Kalraiya, R. D., OGlcNAcylation determines the solubility, filament organization, and stability of keratins 8 and 18. J Biol Chem 2010, 285 (44), 3406271 .
69. Hart, G. W.; Slawson, C.; Ramirez-Correa, G.; Lagerlof, O., Cross talk between O-GlcNAcylation and phosphorylation: roles in signaling, transcription, and chronic disease. Annu Rev Biochem 2011, 80, 825-58.

70. Ribeiro, S. S., Samanta, N., Ebbinghaus, S., Marcos, J.C., The synergic effect of water and biomolecules in intracellular phase separation. Nat Rev Chem 2019, 3, 552-561.

71. Gotor, N. L.; Armaos, A.; Calloni, G.; Torrent Burgas, M.; Vabulas, R. M.; De Groot, N. S.; Tartaglia, G. G., RNAbinding and prion domains: the Yin and Yang of phase separation. Nucleic Acids Res 2020, 48 (17), 9491-9504.

72. Yamaguchi, K. I.; Kuwata, K., Formation and properties of amyloid fibrils of prion protein. Biophys Rev 2018, 10 (2), 517 525 .

73. Zhu, Y.; Willems, L. I.; Salas, D.; Cecioni, S.; Wu, W. B.; Foster, L. J.; Vocadlo, D. J., Tandem Bioorthogonal Labeling Uncovers Endogenous Cotranslationally O-GlcNAc Modified Nascent Proteins. J Am Chem Soc 2020, 142 (37), 15729-15739.

74. Schwartz, J. C.; Cech, T. R.; Parker, R. R., Biochemical Properties and Biological Functions of FET Proteins. Annu Rev Biochem 2015, 84, 355-79.

75. Naganuma, T.; Nakagawa, S.; Tanigawa, A.; Sasaki, Y. F.; Goshima, N.; Hirose, T., Alternative 3'-end processing of long noncoding RNA initiates construction of nuclear paraspeckles. The EMBO Journal 2012, 31 (20), 4020-4034.

76. Sabari, B. R.; Dall'Agnese, A.; Boija, A.; Klein, I. A.; Coffey, E. L.; Shrinivas, K.; Abraham, B. J.; Hannett, N. M.; Zamudio, A. V.; Manteiga, J. C.; Li, C. H.; Guo, Y. E.; Day, D. S.; Schuijers, J.; Vasile, E.; Malik, S.; Hnisz, D.; Lee, T. I.; Cisse, II; Roeder, R. G.; Sharp, P. A.; Chakraborty, A. K.; Young, R. A., Coactivator condensation at super-enhancers links phase separation and gene control. Science 2018, 361 (6400).

77. Boija, A.; Klein, I. A.; Sabari, B. R.; Dall'Agnese, A.; Coffey, E. L.; Zamudio, A. V.; Li, C. H.; Shrinivas, K.; Manteiga, J. C.; Hannett, N. M.; Abraham, B. J.; Afeyan, L. K.; Guo, Y. E.; Rimel, J. K.; Fant, C. B.; Schuijers, J.; Lee, T. I.; Taatjes, D. J.; Young, R. A., Transcription Factors Activate Genes through the Phase-Separation Capacity of Their Activation Domains. Cell 2018, 175 (7), 1842-1855 e16.

78. Toretsky, J. A.; Wright, P. E., Assemblages: functional units formed by cellular phase separation. $J$ Cell Biol 2014, 206 (5), $579-88$.

79. Ranuncolo, S. M.; Ghosh, S.; Hanover, J. A.; Hart, G. W.; Lewis, B. A., Evidence of the involvement of O-GlcNAcmodified human RNA polymerase II CTD in transcription in vitro and in vivo. J Biol Chem 2012, 287 (28), 23549-61.

80. Hardiville, S.; Banerjee, P. S.; Selen Alpergin, E. S.; Smith, D. M.; Han, G.; Ma, J.; Talbot, C. C., Jr.; Hu, P.; Wolfgang, M. J.; Hart, G. W., TATA-Box Binding Protein OGlcNAcylation at T114 Regulates Formation of the B-TFIID Complex and Is Critical for Metabolic Gene Regulation. Mol Cell 2020, 77 (5), 1143-1152 e7.

81. Guo, Y. E.; Manteiga, J. C.; Henninger, J. E.; Sabari, B. R.; Dall'Agnese, A.; Hannett, N. M.; Spille, J. H.; Afeyan, L. K.; Zamudio, A. V.; Shrinivas, K.; Abraham, B. J.; Boija, A.; Decker, T. M.; Rimel, J. K.; Fant, C. B.; Lee, T. I.; Cisse, II; Sharp, P. A.; Taatjes, D. J.; Young, R. A., Pol II phosphorylation regulates a switch between transcriptional and splicing condensates. Nature 2019, 572 (7770), 543-548.

82. Nott, T. J.; Petsalaki, E.; Farber, P.; Jervis, D.; Fussner, E.; Plochowietz, A.; Craggs, T. D.; Bazett-Jones, D. P.; Pawson, T.; Forman-Kay, J. D.; Baldwin, A. J., Phase transition of a disordered nuage protein generates environmentally responsive membraneless organelles. Mol Cell 2015, 57 (5), 936-947.

83. Gross BJ, K. B., Walker S, Discovery of O-GlcNAc transferase inhibitors. J Am Chem Soc 2005, 127, 14588-14589.

84. Hanson, J.; Yang, Y.; Paliwal, K.; Zhou, Y., Improving protein disorder prediction by deep bidirectional long short-term memory recurrent neural networks. Bioinformatics 2017, 33 (5), 685-692. 
bioRxiv preprint doi: https://doi.org/10.1101/2021.05.11.443654; this version posted May 11, 2021. The copyright holder for this preprint (which was not certified by peer review) is the author/funder, who has granted bioRxiv a license to display the preprint in perpetuity. It is made available under aCC-BY-NC 4.0 International license. 
bioRxiv preprint doi: https://doi.org/10.1101/2021.05.11.443654; this version posted May 11, 2021. The copyright holder for this preprint (which was not certified by peer review) is the author/funder, who has granted bioRxiv a license to display the preprint in perpetuity. It is made available under aCC-BY-NC 4.0 International license.

Insert Table of Contents artwork here

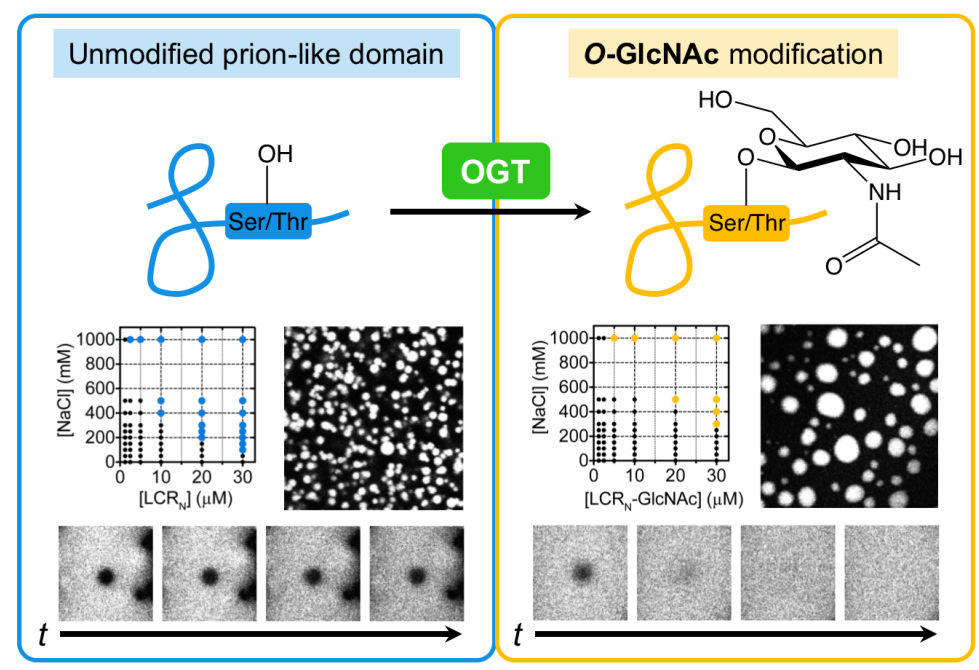

For Table of Contents only. 